Research Article

\title{
Socioeconomic and recharge effect on spatial changes in the groundwater chemistry of Punjab, Pakistan: a multivariate statistical approach
}

\author{
Mumtaz Khan ${ }^{1}$ (D) Waqas Khan ${ }^{2}$
}

Received: 6 December 2019 / Accepted: 24 July 2020 / Published online: 1 August 2020

(c) Springer Nature Switzerland AG 2020

\begin{abstract}
This study presents deterioration in groundwater quality of highly populated region of Punjab Province, Pakistan, by linking chemical data with rain, river recharge, and socioeconomic factors. Various chemical parameters like total dissolved solid (TDS), arsenic (As), fluoride $\left(\mathrm{F}^{-}\right)$, Iron (Fe), nitrate $\left(\mathrm{NO}_{3}{ }^{-}\right)$, nitrite $\left(\mathrm{NO}_{2}{ }^{-}\right)$, and $\mathrm{pH}$ were determined for 46,457 samples collected from $205,344 \mathrm{~km}^{2}$ area of the Punjab. The samples were collected, stored, and analyzed as per the Environment Protection Agency (EPA) methods at laboratory. Commercial kits were used for analysis of $\mathrm{Fe}, \mathrm{As} \mathrm{NO}_{2}{ }^{-}, \mathrm{NO}_{3}{ }^{-}$and $\mathrm{F}^{-}$, while TDS and $\mathrm{pH}$ were measured by respective meters. Chemical parameters were correlated with human and animal population, fertilizers consumption, tube wells, industrial density, rain occurrence, and river recharge rate. Data were analyzed using XLSTAT, and GIS 10.3 was used to draw the maps. Spatial classification of the districts was performed by principal component analysis and hierarchal cluster analysis. TDS, As, $\mathrm{F}^{-}, \mathrm{Fe}, \mathrm{NO}_{3}{ }^{-}, \mathrm{NO}_{2}{ }^{-}$, and $\mathrm{pH}$ were found to be $50-52,360 \mathrm{mg} / \mathrm{L}$, 0-735 $\mu \mathrm{g} / \mathrm{L}, 0-121 \mathrm{mg} / \mathrm{L}, 0-37.2 \mathrm{mg} / \mathrm{L}, 0-2215 \mathrm{mg} / \mathrm{L}, 0-3033 \mathrm{mg} / \mathrm{L}$, and 0.09-10.9, respectively. The study revealed that $66.26 \%$ of the samples were fit for drinking purpose, while $33.74 \%$ were unfit. Further, it was found that $27 \%$ of the samples were non-saline, $26 \%$ were saline, and $47 \%$ were slightly saline based on the World Health Organization drinking water quality criteria. A nonlinear model was developed which explains $57 \%$ of variance in groundwater quality. Based on groundwater quality, the whole province was divided into three main regions: northwestern districts, central districts and southeastern districts. Central Punjab was highly polluted, followed by southeast region, while northwest Punjab has better quality water due to more rains and Indus River. Current study provides a model to predict future water quality of the region and suggests that new water canals in southeast Punjab can improve water quality. Moreover, it is recommended that agriculture and industrial effluents should be controlled to improve water quality, new smart cities should be built along Indus River, and population should be controlled in southeast and central Punjab.
\end{abstract}

Electronic supplementary material The online version of this article (https://doi.org/10.1007/s42452-020-03255-3) contains supplementary material, which is available to authorized users.

Mumtaz Khan, mumtazk36@gmail.com | ${ }^{1}$ Environment Monitoring Group, Health Physics Division, Pakistan Institute of Nuclear Science and Technology, P.O. Nilore, Islamabad, Pakistan. ${ }^{2}$ Government College University Faisalabad, Faisalabad, Pakistan. 


\section{Graphical abstract}
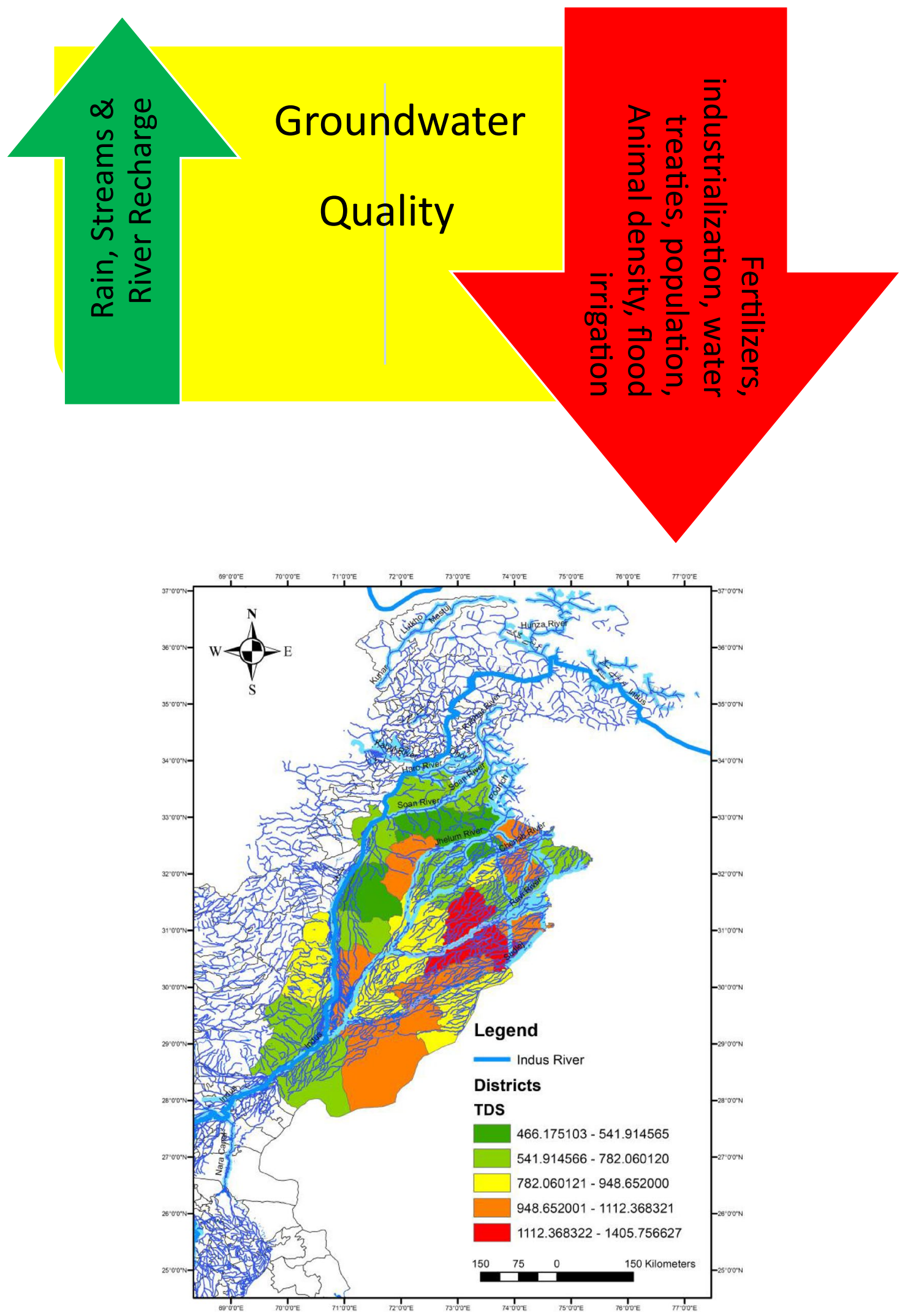
Keywords Punjab · Groundwater · Arsenic · Nitrate · Nitrite · Fluoride

\section{Introduction}

Punjab is a part of upper Indus basin, and during the past two decades, its groundwater chemistry has been changed significantly [1-3]. Shallow ground water in Punjab is 20-200 feet below the ground surface and is used for drinking, agriculture, industrial activities, and farming. Current challenges of the Punjab groundwater are: depletion $[4,5]$, salinization [6], mobilization of arsenic (As), fluoride $\left(\mathrm{F}^{-}\right)$[7], uranium $(\mathrm{U})[8]$, and nitrate $\left(\mathrm{NO}_{3}{ }^{-}\right)$[9]. Substantial number of samples were found in the eastern Punjab region having traces of toxic pollutants $(\mathrm{Pb}, \mathrm{Cr}, \mathrm{Ni}, \mathrm{Cd}, \mathrm{Cu}$, $\mathrm{As}, \mathrm{Fe}, \mathrm{F}^{-}$, and $\mathrm{Mn}$ ) with higher concentration than the WHO limits $[2,10,11]$. Lahore and Kasur groundwater is severely contaminated with $\mathrm{F}^{-}$and $\mathrm{As}$, and $20-70 \%$ of the samples from Lahore have higher $\mathrm{F}^{-}$level than $1.5 \mathrm{mg} / \mathrm{L}$ [12]. Another study showed $19 \%$ samples from Punjab have higher $\mathrm{NO}_{3}{ }^{-}$than WHO level of $10 \mathrm{mg} / \mathrm{L}$ [11]. A survey of 383 villages of Punjab showed $23 \%$ samples have As greater than $10 \mu \mathrm{g} / \mathrm{L}$, while $11 \%$ exceed $50 \mu \mathrm{g} / \mathrm{L}$. Most of these villages lie across River Ravi which has been dried up after promulgation of Indus water treaty [13]. Maximum value of $A s$ and $F^{-}$in east and south Punjab districts was 906-1000 $\mu \mathrm{g} / \mathrm{L}$ and $2.8-8.6 \mathrm{mg} / \mathrm{L}$, respectively $[14,15]$. Drinking of polluted groundwater has resulted in dental, skeletal fluorosis, hyperthyroidism (goiter), methemoglobinemia, gastric cancer, goiter, birth malformations, and hypertension in the region [16-19].

Geological studies revealed anthropogenic sources are polluting groundwater, as shallow aquifer has high As [20] and $\mathrm{F}^{-}$than deep aquifer [21]. Therefore, it is expected that socioeconomic sources are playing more significant role in controlling groundwater quality than geochemical factors [21-24]. Fertilizer consumption has been increased manifold in the last three decades. Such excessive use of fertilizers in various agricultural areas of Punjab played a vital role in groundwater pollution. Two to three decades ago, $\mathrm{F}^{-}$in groundwater was related to arid conditions or natural rocks weathering, as fluorspar, cryolite, fluorapatite, and hydroxyapatite were found in local rocks [17-19, 25-27]. Later studies changed the narrative of sources, as sulfate $\left(\mathrm{SO}_{4}{ }^{2-}\right), \mathrm{As}$, and $\mathrm{F}^{-}$were detected in rain [28]. Industrial waste, household water, and coal burning are source of As and $F^{-}$as maximum values of $2400 \mu \mathrm{g} / \mathrm{L}$ and $22.8 \mathrm{mg} / \mathrm{L}$ have been reported near an industrial zone in Lahore which decreases away from zone [21,22]. Local diammonium phosphate (DAP) and coal contain $\mathrm{F}^{-} 25-255 \mathrm{mg} / \mathrm{L}$ [28] and 5-20 mg/L, respectively, while same DAP contains As $5-10 \mathrm{mg} / \mathrm{Kg}[22,23]$. Nitrogen $\left(\mathrm{NO}_{3}{ }^{-1}\right.$ vs. $\left.\mathrm{N}\right)$ data also show that animal waste has contributed to nitrate pollution. These anthropogenic sources contributed significantly to the rising level of phosphate $\left(\mathrm{PO}_{4}{ }^{3-}\right), \mathrm{SO}_{4}{ }^{2-}$, $\mathrm{NO}_{3}{ }^{-}, \mathrm{As}, \mathrm{F}^{-} \mathrm{Fe}, \mathrm{NO}_{2}{ }^{-}$and carbonate $\left(\mathrm{CO}_{3}{ }^{2-}\right)$ in groundwater $[17,22,24]$.

Rawalpindi, Kasur, and Bahawalpur groundwater contains $\mathrm{Ca}^{2+}-\mathrm{HCO}_{3}{ }^{-}, \mathrm{Na}^{+} / \mathrm{K}^{+}-\mathrm{HCO}_{3}{ }^{-} / \mathrm{Cl}^{-}$and $\mathrm{Na}^{+} /$ $\mathrm{K}^{+}-/ \mathrm{HCO}_{3}{ }^{-} / \mathrm{SO}_{4}{ }^{-2}$ as dominating ions, respectively [15]. $\mathrm{Na}^{+}-\mathrm{Cl}^{-} / \mathrm{Na}^{+}-\mathrm{HCO}_{3}{ }^{-}$type groundwater [15] with higher $\mathrm{F}^{-}$, $\mathrm{As}$, and $\mathrm{NO}_{3}{ }^{-}$as common contaminants is reported in many eastern and south Punjab [29]. High $\mathrm{Na}^{+}-\mathrm{HCO}_{3}{ }^{-}$water is formed by silicate and carbonate weathering and evapotranspiration at high $\mathrm{pH}$ in addition to anthropogenic factors (agriculture return, domestic sewage, and fertilizer) $[18,28]$ and promotes $\mathrm{F}^{-}$and As dissolution [22] with low $\mathrm{Ca}^{2+}$ and $\mathrm{Mg}^{2+}[29]$, low $\mathrm{NO}_{3}{ }^{-}$, high $\mathrm{Fe}$ and $\mathrm{SO}_{4}{ }^{2-}$ [29]. Higher $\mathrm{As}$ and $\mathrm{F}^{-}$in shallow groundwater than in deep groundwater are found in south Punjab [29] which is different from east Punjab, Lahore [28]. Release of As in east Punjab may be due to reductive dissolution of $\mathrm{FeO}(\mathrm{OH})$ with dissolved organic matter (natural or anthropogenic from animal or agriculture) [20], while south Punjab As release can be due to oxidative/evaporative mechanism, in addition to phosphate interaction at high pH [29]. Saline intrusion is also result of water tube well extraction [28, 30]. Rock-water interaction is accelerated with aquifer overexploitation which might have enriched $\mathrm{F}^{-}$and $\mathrm{As}$ in the deep groundwater [15] as observed in some wells in south Punjab [31].

Currently, Ravi and Sutlej have less than 2 MAF average water flow near Balloki and Sulemanki barrages, while it was 10-12 MAF in 1980. Indus, Jehlam, and Chenab have average annual flow of 62,23 , and 25 MAF with seasonal variation, and decreasing volume trend is observed till present; as a result, water deficit is reported in 25 main canals [32]. Canal irrigation system raised water table during British era [33,34], while current agriculture practices has lowered the water table due to water abstraction at rate of $2.1 \mathrm{~km}^{3} \mathrm{yr}^{-1}$ [35]. Local recharge is also reduced due to construction of cemented water channels to provide water to tail end farmers. Groundwater quality is generally fresh along the rivers except in Bari Doab (Ravi and Sutlej Rivers in Bari Doab are dried and carry sewage water) and deteriorates as it moves away from the rivers toward the central parts of the Doabs $[2,36,37]$.

After Indus water treaty, river hydrology and recharge patterns have been changed and rate of socioeconomic development varies in different districts [35, 39-41]; therefore, comparative impact of these changes on groundwater quality should be determined at macroscopic level rather than site-specific studies. There are 36 districts in 
Punjab while past studies are mostly focused on specific sites in few districts, especially Bari Doab or central Punjab, while less data are available of western districts [37, 38]. Current study is conducted to determine groundwater trace pollutants: $\mathrm{As}, \mathrm{F}^{-}, \mathrm{Fe}, \mathrm{NO}_{3}{ }^{-}, \mathrm{NO}_{2}{ }^{-}, \mathrm{pH}$, and TDS (salinity) of all village/towns of 36 districts and compare with socioeconomic factors like tube wells, population, animal population, fertilizer consumption, industries per square kilometer of respective region. The comparison will reveal relative pollution in these districts and their relation with the anthropogenic sources. This study aims to determine spatial variation of groundwater quality based on recharge from various sources and provides a model to predict changes in groundwater salinity in the future. Current research enhances understanding that change in river hydrology due to India-Pakistan water treaty has influenced groundwater pollution significantly in addition to anthropogenic sources of pollution.

\section{Materials and methods}

\subsection{Study area}

Punjab has population of $110,012,442$, and it borders with Sindh toward south, Khyber Pakhtunkhwa toward the west, Baluchistan toward southwest; Islamabad, Azad Jammu and Kashmir toward north. It borders with Indian state of Punjab and Rajasthan toward east (Fig. 1a). It is located between latitude $27.42^{\circ}-34.02^{\circ}$ north and longitude $69.18^{\circ}-75.23^{\circ}$ east. Total land area is $205,344 \mathrm{~km}^{2}$ which contributes $25.8 \%$ of the total land of Pakistan. It stretches $1078 \mathrm{~km}$ north to south and $616 \mathrm{~km}$ from east to west [39].

\subsection{Hydrogeology}

Punjab is covered by $200 \mathrm{~m}$ alluvium originated from Himalaya underlain by Precambrian basement rock [28]. Unconfined aquifer of Punjab has alluvial plain comprising more than $350 \mathrm{~m}$ thick Holocene and Pleistocene sediments transported by Indus and tributaries $[40,41]$ directly overlain by the metamorphic, sedimentary, and igneous rocks of Precambrian age $[2,6]$. These sediments consist of fine to very fine sand and low organic matter [42]. Area between Sutlej and Ravi is called Bari Doab, between Ravi and Chenab rivers, Rechna Doab; Chenab and Jehlam Rivers, Jech Doab; Jehlam and Indus Rivers, Sind Sagar Doab [42].

\subsubsection{Eastern rivers}

There were five rivers flowing through Punjab before 1960, and one river flows along border districts (Indus River). River Jehlam joins Chenab at Trimmu near Jhang. Both join Ravi at Sidhnai near Ahmedpur Sial. Beas River joins Sutlej at Kapurthala and Sutlej-Beas joins Jehlam-Chenab-Ravi at Uch near Bahawalpur to form Panjnad. Punjab has semiarid and subtropical continental climate with sultry summers and cold winters [28].

\subsubsection{Western rivers}

Gilgit River joins Indus near Juglot, and Kunar and Swat join Kabul River near Jalalabad. Combined stream of Kabul joins Indus near Attock. Kurram River (320 km) joins Indus near Isa Khel. Gomal joins Zhob near Khajuri Kach, and combined stream of Zhob stretches $161 \mathrm{~km}$ and joins Indus near Dera Ismail Khan $[43,44]$. Combined stream of Sutlej-Beas-Ravi-Chenab-Jehlam stretches $45 \mathrm{~km}$ southwest and joins Gilgit-Kabul-Kurram-Zhob-Indus stream at Mithankot to form mighty Indus River. Mighty Indus passes through Rajanpur and Rahim Yar Khan (R-Y-Khan) before entering Sindh Province.

\subsubsection{Surface water budget}

Mangla (near Jehlam) and Chasma (near Mianwali) lakes are located inside Punjab. Chenab and Jehlam have 48.68 million acre feet (MAF) of total flow; Indus at Kalabagh (near Mianwali) has 89.71 MAF during summer; Ravi and Sutlej at Balloki \& Sulemanki have 4.23 and 2.59 MAF of maximum flow during summer. Total escapage to sea is 39-50 MAF [43]. There are 23 major canals stretches over $34,500 \mathrm{~km}$ having capacity of 65 billion cubic meter surface water. Punjab has 13 barrages, 2 siphons, and 10 link canals (Rasul-Qadirabad, Qadirabad-Balloki, Balloki-Sulemanki, Trimmu-Sidhnai, Sidhnai-Mailsi, Mailsi-Bahawal, Chasma-Jehlam, Taunsa-Panjnad link-canals). There are 135 surface drainages including 670 drains, with total length of $6600 \mathrm{~km}$ which drain 5.79 million hectares. During 1999-2000, total irrigated area was 13.8 million hectares, out of which 11 million acres are in canal command $[45,46]$.

\subsubsection{Aquifers}

Pothwar plateau (Jehlam, Chakwal, Rawalpindi, and Attock) has separate confined groundwater aquifer [47, 48]. Baluchistan and southwest Punjab also separated through Sulaiman range [35]. Northwestern, western, and southeastern Punjab aquifer is not connected to outside; however toward north and northeastern side, aquifer is 
Fig. 1 a Current study area of the Punjab, Pakistan, for groundwater quality. b Samples location and number of samples from various districts

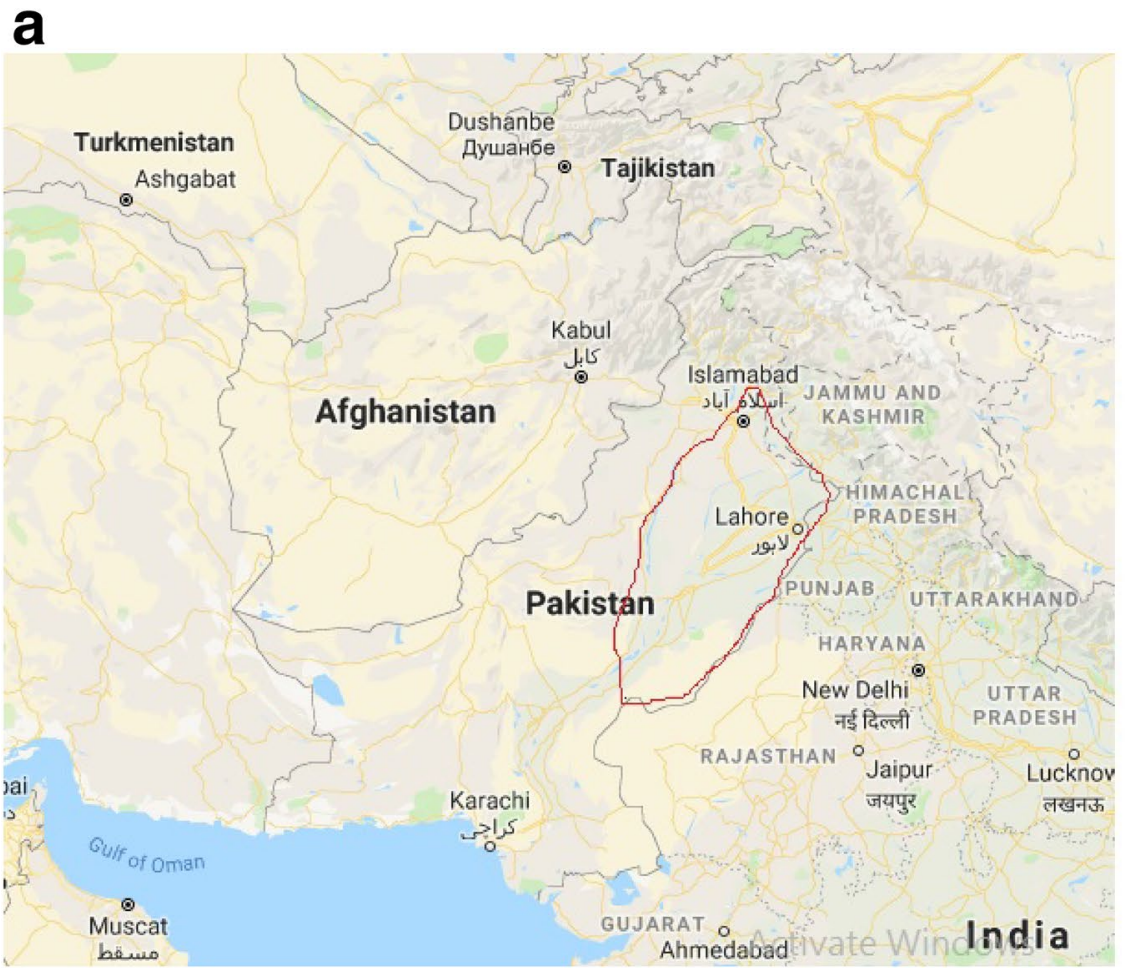

b

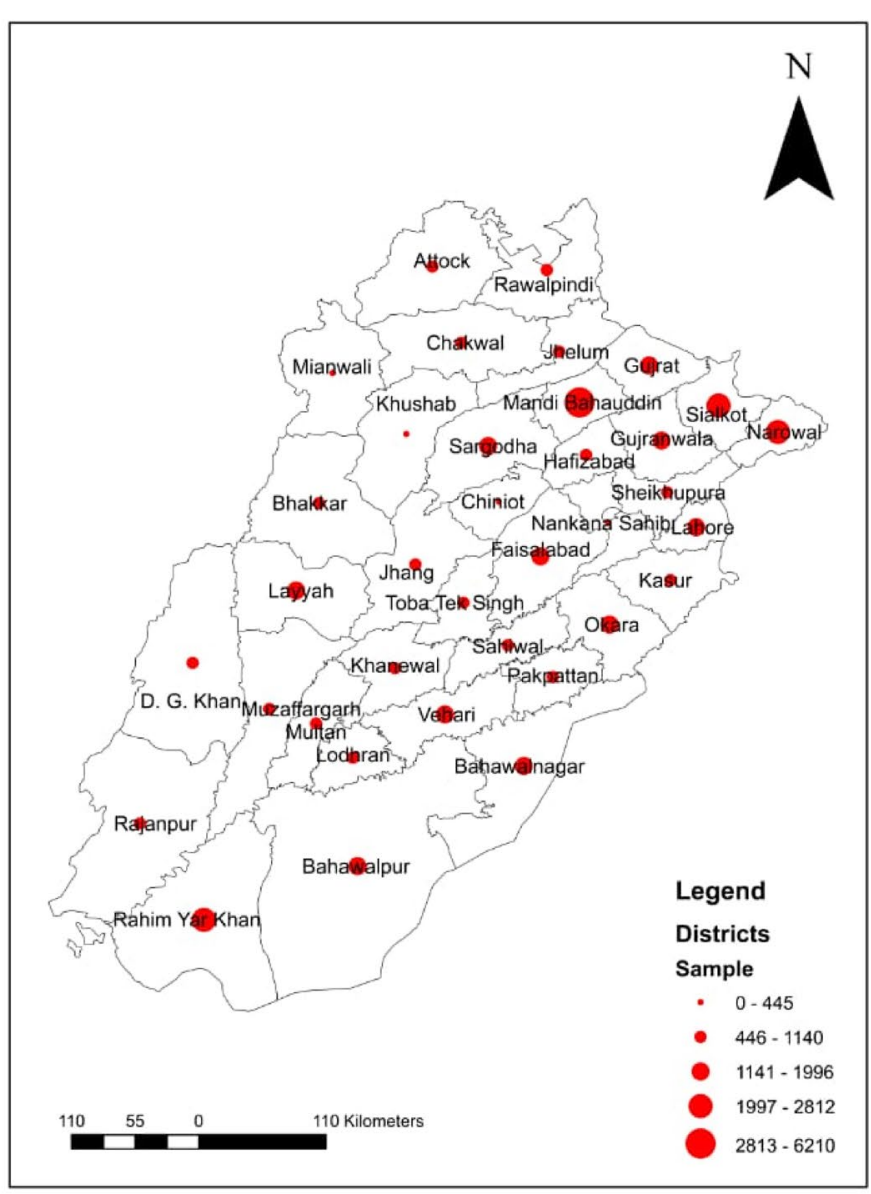


extended and it forms unconfined aquifer [10]. Total recharge is 42.75 MAF, and it includes 9.90 MAF rainfall recharge, 21.70 MAF canal system, 7.08 MAF irrigation return, 3.50 MAF river recharge, and 0.57 MAF domestic and industrial return flow. Total tube well discharge is 31.50 MAF, domestic and industrial discharge is 2.50 $\mathrm{MAF}$, and 8.75 MAF is losses. Total discharge is $42.75 \mathrm{MAF}$ [49]. According to a recent estimate, total ground water abstraction is $50 \mathrm{MAF}$ with 1 million tube wells [46].

\subsection{Data acquisition and mapping}

Punjab is administratively divided into districts, tehsils, and towns/villages. Samples were collected from front, center, and backside of each town/locality. Three samples were taken from each village and averaged for that locality. Total 46,457 samples were collected from whole Punjab Province during January 2014 to December 2016 (Fig. 1b). TDS and $\mathrm{pH}$ were measured with TDS and $\mathrm{pH}$ meters, made of Hanna Instruments model HI98192 and HI98190, respectively right after sampling. Other chemical moieties (As, $\mathrm{F}^{-}, \mathrm{Fe}, \mathrm{NO}_{3}^{-}$, and $\mathrm{NO}_{2}{ }^{-}$) were analyzed in the laboratory $[50,51]$ with kits made of ChemMetrics. Rain data were collected from regional meteorological stations. Population, industries, livestock, fertilizers, and tube wells data were taken from statistical pocket book of the Punjab government [52] and converted to density data (per $\mathrm{km}^{2}$ ) after dividing by the area of each district. Socioeconomic density and rain data were used to discuss groundwater quality pollution. All chemical, hydrological, and socioeconomic parameters have been mapped using GIS, version 10.3 .

\subsection{Data mining}

Hierarchal cluster analysis (HCA) is an exploratory data mining technique that extracts and classifies data into various groups [53-56]. HCA was performed after $z$ transformation by Ward's method with Euclidean distance as measure of similarity using XLSTAT [57-59]. Districts of the Punjab were classified into three groups by HCA and principal component analysis (PCA), $[53,57,58]$ based on water quality parameters (TDS, As, $\mathrm{Fe}, \mathrm{F}^{-}, \mathrm{NO}_{3}{ }^{-}, \mathrm{NO}_{2}{ }^{-}$, and $\mathrm{pH}$ ), socioeconomic parameters (human and animal population, fertilizers sale, tube wells, industrial density), and climate parameters (rain, river recharge) [60]. Guildford's rule of thumb was applied for interpreting correlation coefficients $[60,61]$.

\subsection{Predictive modeling}

Various socioeconomic factors affect groundwater quality; therefore, multiple nonlinear regression model was selected [62-64] to predict influence of each factor on TDS in the future. A generalized nonlinear model was applied (Eq. 1) using 3 degree polynomial to predict overall water quality parameters (TDS) for given values of socioeconomic/climate parameter. Equation $1[62,63,65]$ is valid unless seepage rate from the rivers and streams remains at current level.

$Y=p r 1+p r 2 \times X 1+p r 3 \times X 2+p r 4 \times X 3 \ldots$

\section{Results and discussion}

Various elements' concentration was determined including $\mathrm{As}, \mathrm{F}^{-}, \mathrm{Fe}, \mathrm{NO}_{3}{ }^{-}, \mathrm{NO}_{2}{ }^{-}$, and $\mathrm{pH}$ (Fig. 2). Most of the ions $\left(\mathrm{F}^{-}\right.$, $\mathrm{Fe}, \mathrm{NO}_{3}{ }^{-}$, and $\mathrm{NO}_{2}{ }^{-}$) average values were high than WHO limits in certain districts (Tables 1, 2, and 3 in supporting information). Based on WHO drinking level criteria, $66.26 \%$ samples were fit, while $33.74 \%$ were unfit for drinking [66-70]. Close observation of spatial maps (Fig. 2) for all parameters ( $\mathrm{Fe}, \mathrm{F}^{-}, \mathrm{As}$, and TDS) show two main pattern of distributions, i.e., southeast side (along India border) has more deteriorated water than northwestern side (bordering Khyber Pakhtunkhwa (KPK), Gilgit-Baltistan (GB), and Azad Kashmir). Water quality is better in those districts where Indus, Jehlam, and Chenab Rivers are flowing. Previous studies have reported fresh water up to $50 \mathrm{~km}$ area around Indus and its tributaries [2, 10], while areas around Ravi and Sutlej Rivers have deteriorated groundwater quality.

\subsection{Main contaminants}

Mean, median, and mode values of As for Punjab were $12.83,5.00$, and $0.00 \mathrm{mg} / \mathrm{L}$, respectively (Table 1 ) $[28,66]$. Indus gigantic basin (IGB) has As $<10 \mu \mathrm{g} / \mathrm{L}$ [2], and current studies found As $0-735 \mu \mathrm{g} / \mathrm{L}$ in Punjab. A survey reported $3 \%$ of Punjab population is exposed to As $>50 \mu \mathrm{g} / \mathrm{L}$ [66], while $20 \%$ population is exposed to As $>10 \mu \mathrm{g} / \mathrm{L}[71$, 72]. Shallow water study in 2001 revealed $9 \%$ samples contain As $>10 \mu \mathrm{g} / \mathrm{L}$ [66], whereas $0.7 \%$ of samples contain $>50 \mu \mathrm{g} / \mathrm{L}$ [28]. Samples (46,457 samples) analyzed in current study are more than in previous studies, and it was found that $2.53 \%$ samples have As $>50 \mu \mathrm{g} / \mathrm{L}$, while $8.07 \%$ have As $>10 \mu \mathrm{g} / \mathrm{L}$. Higher As is already reported in cities around rivers: Lahore [73], Kasur, Bahawalpur, Sahiwal, R-Y-Khan, Muzaffargarh [71], while current study (Fig. 2, Tables 1, 2, and 3 in supporting information) found mode of Lahore, Muzafar Garh, and Kasur was $50 \mu \mathrm{g} / \mathrm{L}, 50 \mu \mathrm{g} / \mathrm{L}$, and $10 \mu \mathrm{g} / \mathrm{L}$, respectively. Maximum value of As in Kasur and Muzafar Garh districts is $906-1000 \mu \mathrm{g} / \mathrm{L}[14,15]$. 
a

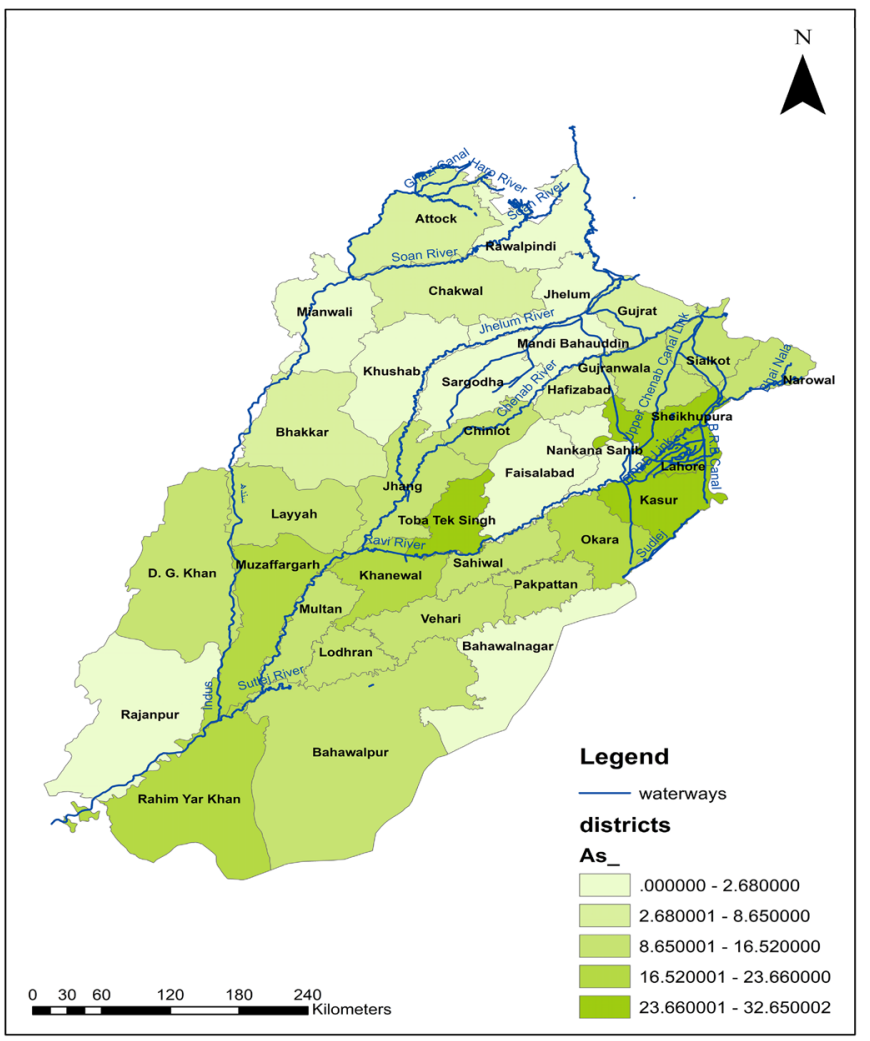

b

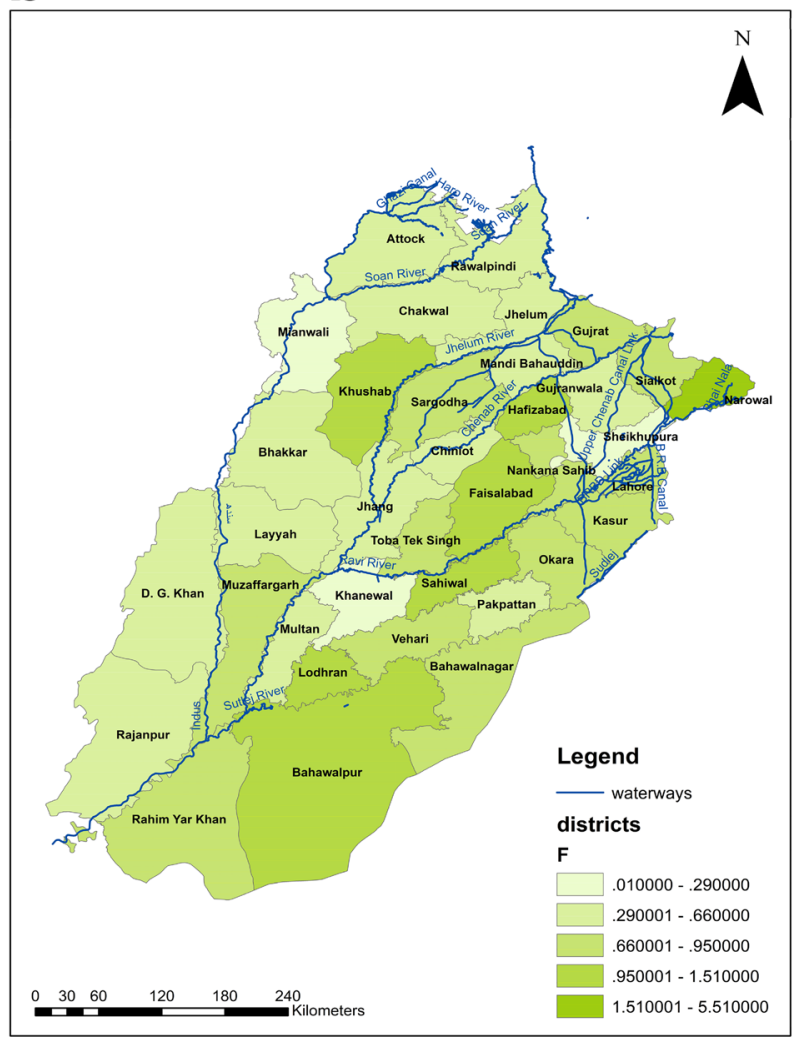

Fig. 2 a-g Spatial distribution of (mean values) As ( $\mu \mathrm{g} / \mathrm{L}), \mathrm{F}^{-}(\mathrm{mg} / \mathrm{L}), \mathrm{Fe}(\mathrm{mg} / \mathrm{L}), \mathrm{NO}_{2}^{-}(\mathrm{mg} / \mathrm{L}), \mathrm{NO}_{3}^{-}(\mathrm{mg} / \mathrm{L}), \mathrm{pH}$, and TDS (mg/L) of Punjab, Pakistan

Arsenic in groundwater can be present due to both natural and anthropogenic factors. Arsenic may release from earth crust due to geological settling $[10,71]$, argillaceous and organic matter with fine-medium sands of Holocene alluvium [74-76]. Arsenic is desorbed from metal surface to the groundwater due to alkaline environment, as southeast have mostly alkaline groundwater [73]. Arsenic in shallow water is found to be higher than in groundwater because of anthropogenic sources like coal, diammonium phosphate [22] fertilizer, hydrofluorocarbon, and trifluoromethyl pesticide [22]. Detection of As in rain also verifies that commercial activities are releasing the metal [28]. Positive correlation coefficient (Table 2) was found between As versus industries (0.33), human population density (0.38), animal population density $(0.31)$, and fertilizers (0.40); while negative correlation was found between As versus rain (-0.22). Current studies correlation data suggest that As is significantly contributed by commercial sources.

Mean, median, and mode of $\mathrm{F}^{-}$of Punjab were 0.74 , 0.52 , and $0.00 \mathrm{mg} / \mathrm{L}$, respectively (Table 1 ). Mean $\mathrm{F}^{-}$was 1.51 and $5.51 \mathrm{mg} / \mathrm{L}$ in Khushab and Narowal, respectively (Table 1 in supporting information, Fig. 2b). In Punjab as a whole, $10.63 \%$ samples were found to have $\mathrm{F}^{-}>1.5 \mathrm{mg} / \mathrm{L}$ while $45.77 \%$ sample found to have $F^{-}>0.5 \mathrm{mg} / \mathrm{L}$. Maximum WHO limit is $1.5 \mathrm{mg} / \mathrm{L}$ [67], and it was alarming that significant percentage was higher than WHO limit [12]. Positive correlation was found between $\mathrm{F}^{-}$versus rain (0.17), tube well density (0.39), and fertilizers (0.18) (Table 2). High values of $\mathrm{F}^{-}$were found in southeast side (Fig. 2).

Mean, median, and mode of Fe of Punjab were 0.13, 0.04 , and $0.00 \mathrm{mg} / \mathrm{L}$ respectively (Table 1 ). Samples having $\mathrm{Fe}>1 \mathrm{mg} / \mathrm{L}$ were $0.42 \%$, while samples having $\mathrm{Fe}>0.1 \mathrm{mg} / \mathrm{L}$ were $15.27 \%$. Punjab Fe range was $0-37.20 \mathrm{mg} / \mathrm{L}$ and positive correlation was found between Fe vs. animal density (0.16), and fertilizer sale (0.31). Highest average Fe was $1.02 \mathrm{mg} / \mathrm{L}$ in Sahiwal (WHO limit $\leq 1 \mathrm{mg} / \mathrm{L}$ ), while Gujrat $(0.61 \mathrm{mg} / \mathrm{L})$, Rajanpur (0.34 mg/L), Chiniot (0.29 mg/L), Gujranwala \& Nankana Sahib (0.28 mg/L each), Pakpattan ( $0.27 \mathrm{mg} / \mathrm{L})$, Sialkot and Okara $(0.24 \mathrm{mg} / \mathrm{L}$ each) also have higher values.

Mean, median, and mode of $\mathrm{NO}_{3}{ }^{-}$of Punjab were 9.93, 0.00, and $0.00 \mathrm{mg} / \mathrm{L}$, respectively (Table 1 ). Samples have $\mathrm{NO}_{3}{ }^{-}>50 \mathrm{mg} / \mathrm{L}$ were $1.33 \%$, while samples having $\mathrm{NO}_{3}{ }^{-}>10 \mathrm{mg} / \mathrm{L}$ were $10.48 \%$ as compared to previous 


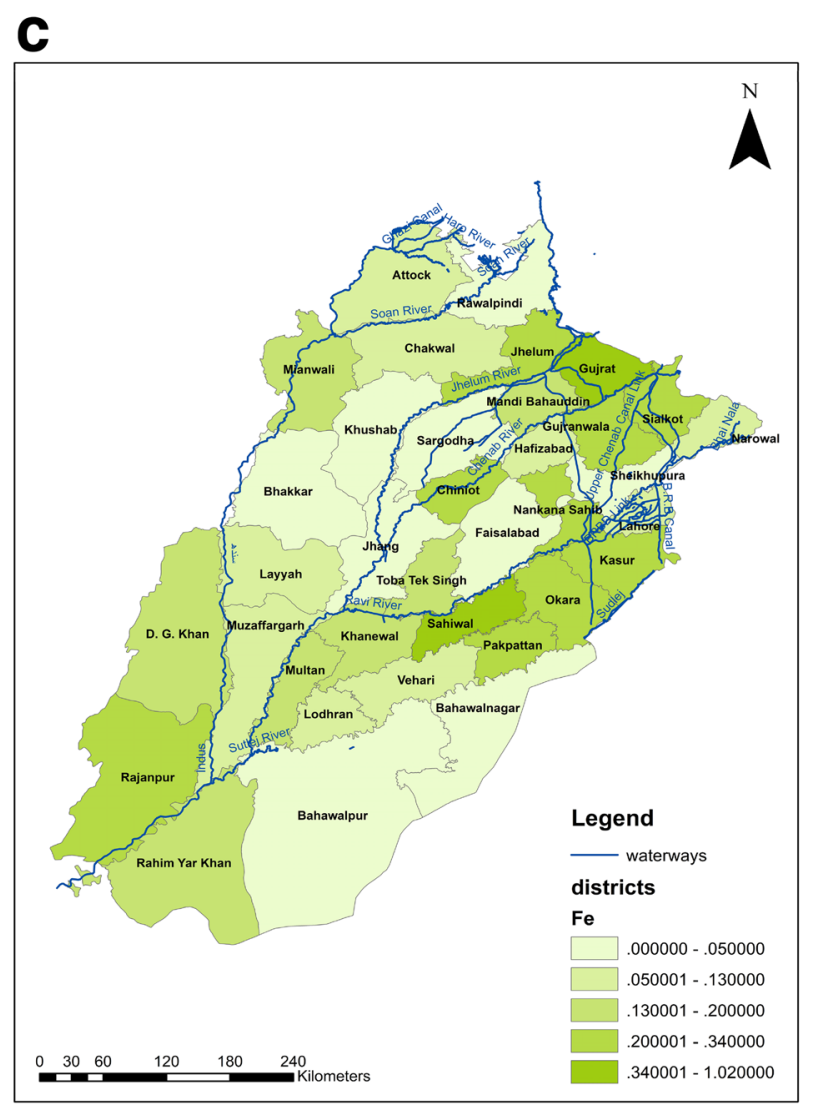

Fig. 2 (continued)

reports that showed $19 \%$ of samples exceed $10 \mathrm{mg} / \mathrm{L}$. Current study sampling points are more than previous study (399) [11]; therefore, it is reliable. Many districts (47.2\%) have mean $\mathrm{NO}_{3}{ }^{-}$greater than WHO limit (Table 1 in supporting information) [68]. Highest mean $\mathrm{NO}_{3}{ }^{-}$was 49.94 and 55.04 in Okara and Sialkot, respectively. Fresh water sources have less $\mathrm{NO}_{3}{ }^{-}$; as central Himalaya, oceans, and rivers have $0.56 \mathrm{mg} / \mathrm{L}, 0.67 \mathrm{mg} / \mathrm{L}$, and $1 \mathrm{mg} / \mathrm{L}$ [77]. Positive correlation coefficient of $0.24,0.31,0.36,0.19$, and 0.12 was found between $\mathrm{NO}_{3}{ }^{-}$versus rain, industries, tube wells, population density, and animal density, respectively. The highest sale of fertilizer was recorded in Okara in 2013-2014, and high $\mathrm{NO}_{3}{ }^{-}$in Okara can be due to high rate of application of agriculture fertilizer and Maize/corn cultivation. High- $\mathrm{NO}_{3}{ }^{-}$districts lie in southeast side than in northwest (Fig. 2e). Fertilizer consumption in southeast Punjab is higher than in northwest part. Boiler industry can contribute higher $\mathrm{NO}_{3}{ }^{-}$[78] due to higher population in southeast than in northwest. Concentration of nitrates can be high due to flood irrigation/rain seepage $[79,80]$ of fertilized land, animal waste, septic tanks and sewage dumps leaching [11].

Mean, median, and mode of $\mathrm{NO}_{2}{ }^{-}$of Punjab were $0.82,0.00$, and $0.00 \mathrm{mg} / \mathrm{L}$, respectively (Table 1 ). d

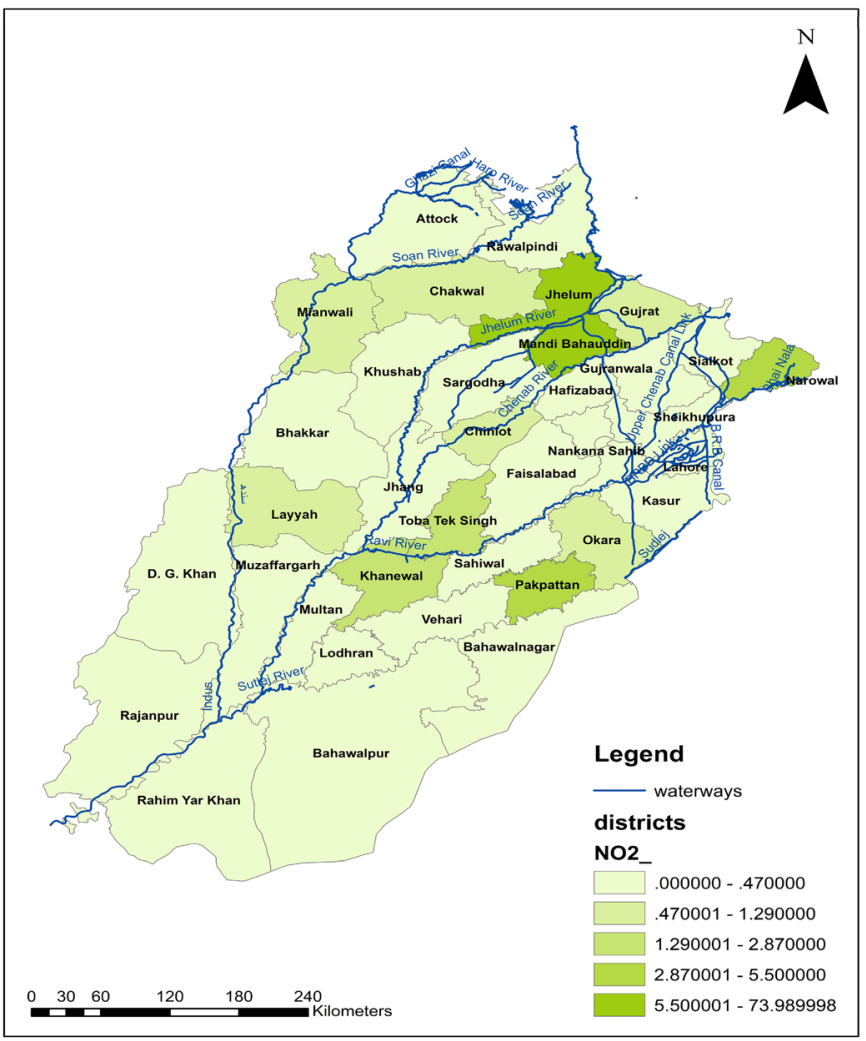

Samples having $\mathrm{NO}_{2}{ }^{-}>3 \mathrm{mg} / \mathrm{L}$ were $0.92 \%$, while samples having $\mathrm{NO}_{2}^{-}>1 \mathrm{mg} / \mathrm{L}$ were $3.82 \% . \mathrm{NO}_{2}{ }^{-}$was found in 0-3033 mg/L range in the Punjab Province. District-wise mean $\mathrm{NO}_{2}{ }^{-}$was $53.16,73.99,4.20,5.5$, and 2.87 in Jehlam, MB-Din, Narowal, Pakpattan, and TT Singh, respectively. There are two distinct groups of district where $\mathrm{NO}_{2}^{-}$was high, but these were not geographically connected and belong to different aquifers. As $\mathrm{NO}_{2}{ }^{-}$was positively correlated with rain $(0.30)$ and tube well density $(0.27)$, it is suspected that $\mathrm{NO}_{2}^{-}$in Jehlam is due to water logging, while high $\mathrm{NO}_{2}^{-}$in Pakpattan might be due to flood irrigation and agriculture practices.

Mean, median, and mode of pH of Punjab were 7.59, 7.50 , and 7.40 , respectively for 46,457 samples (Table 1 ). $\mathrm{pH}$ range was found in range of $0.09-10.90$, while northwestern side has less $\mathrm{pH}$ than southeastern side. Samples having $\mathrm{pH}>7$ were $81.84 \%$, showing overall alkaline trend. Only $1.1 \%$ samples do not fall into $\mathrm{WHO} \mathrm{pH}$ limit as $0.2 \%$ had $\mathrm{pH}>9.2$, while $0.90 \%$ had $\mathrm{pH}<6.5$. Previous studies suggested alkaline $\mathrm{pH}$ due to meteoric origin of the groundwater [73]. $\mathrm{pH}$ was negatively correlated with rain $(-0.27)$ and tube wells $(-0.37)$ similar to TDS. As southeast is more alkaline than northwest, it is suggested in addition 
e

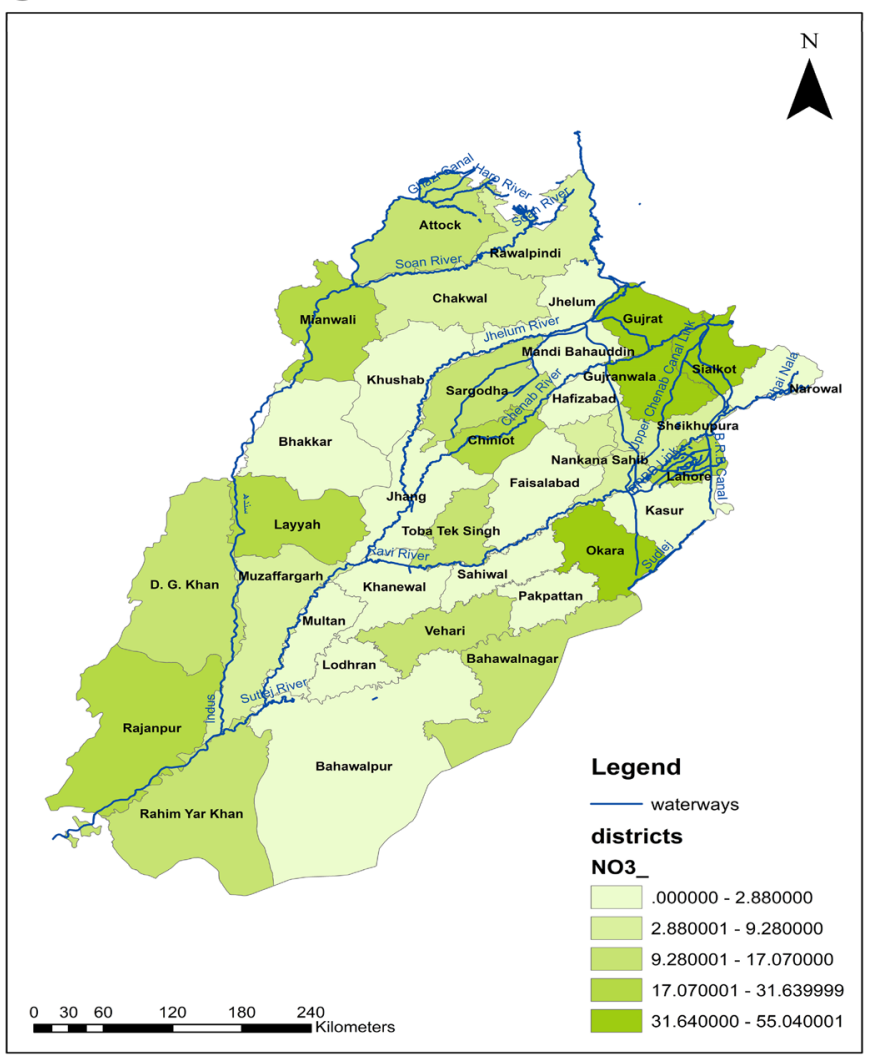

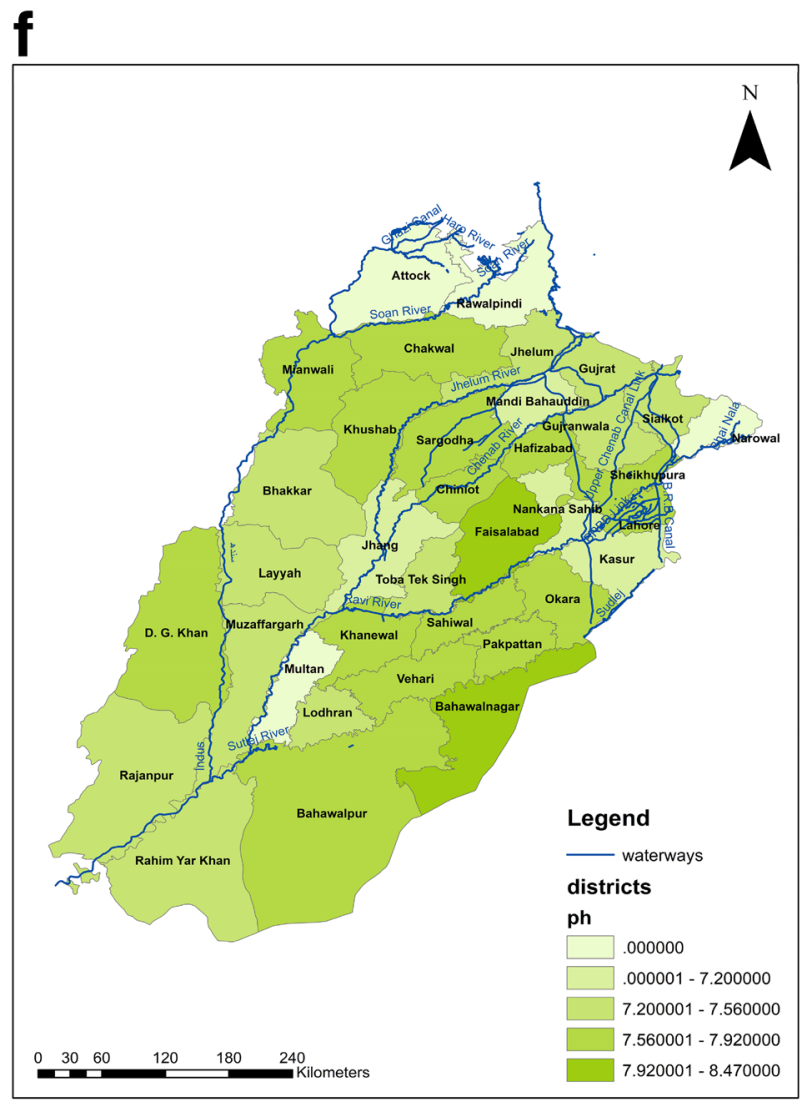

Fig. 2 (continued)

to natural factors, socioeconomic factors are also contributing to alkaline $\mathrm{pH}$.

TDS comprises all dissolved inorganic ions (principally calcium, magnesium, potassium, sodium, bicarbonates, chlorides, and sulfates) and dissolved organic matter [70, 81] and represents overall water quality. Food and agriculture organization (FAO) classifies water as non-saline when TDS is $<500 \mathrm{mg} / \mathrm{L}$; slightly saline $500-1000 \mathrm{mg} / \mathrm{L}$; saline $1000-2500 \mathrm{mg} / \mathrm{L}$ and highly saline when TDS is $>2500 \mathrm{mg} / \mathrm{L}$ [82]. WHO suggests $<600 \mathrm{mg} / \mathrm{L}$ is good quality, while it specifies $1000 \mathrm{mg} / \mathrm{L}$ as upper drinking limit $[69,83]$.

Mean, median, and mode of TDS of Punjab were $862.67 \mathrm{mg} / \mathrm{L}, 700 \mathrm{mg} / \mathrm{L}$, and $560 \mathrm{mg} / \mathrm{L}$ (Table 1). Current study found samples having TDS $>1000 \mathrm{mg} / \mathrm{L}$ were $26 \%$, while samples having TDS 500-1000 $\mathrm{mg} / \mathrm{L}$ were $47 \%$ and TDS $<500 \mathrm{mg} / \mathrm{L}$ samples were $27 \%$. Punjab TDS range was found to be $50-52,360 \mathrm{mg} / \mathrm{L}$. Southeast side has high values than northwest side (Fig. 2). Another study about IGB showed $23 \%$ samples have salinity $>1000 \mathrm{mg} / \mathrm{L}[2,10]$. Previous studies showed TDS of Lahore was $442-2573 \mathrm{mg} / \mathrm{L}$ and two-third samples in Lahore had higher TDS due to $\mathrm{Na}-\mathrm{Cl}$ type water, while one-third is due to $\mathrm{Na}-\mathrm{HCO}_{3}[12]$. Positive correlation coefficients were found between TDS vs. industrial density (0.40), human population (0.19), animal population density $(0.24)$, and fertilizer sale density (0.53), while negative correlation coefficient was found for rain $(-0.28)$. Previous studies suggested meteoric origin of water is cause of higher TDS, in addition to socioeconomic factors found in the current study [73].

\subsection{HCA}

Hierarchical cluster analysis (HCA) has divided districts into three classes based on mean and median (Tables 3 and 4, Fig. 3). Districts around Indus River, especially Sind Sagar Doab, Pothwar and western side, were put into class 2 (non-saline), while districts between River Ravi and Sutlej (Bari Doab), Chenab and Ravi (lower Rechna) and lower Jech Doab (downward to Sargodha) were put into class 1 (slight saline). Okara and Faisalabad that are districts of worst quality water, were put into third class (saline).

This classification proved that water streams and rain are affecting overall groundwater chemistry and less recharge is deteriorating water quality. Higher rain recharge is also increasing $\mathrm{NO}_{2}^{-}$pollution in Jehlam, Chakwal, and MB-Din (Fig. 2) as 0.3 correlation coefficient (Table 2) was found in whole of Punjab. Higher mean of 


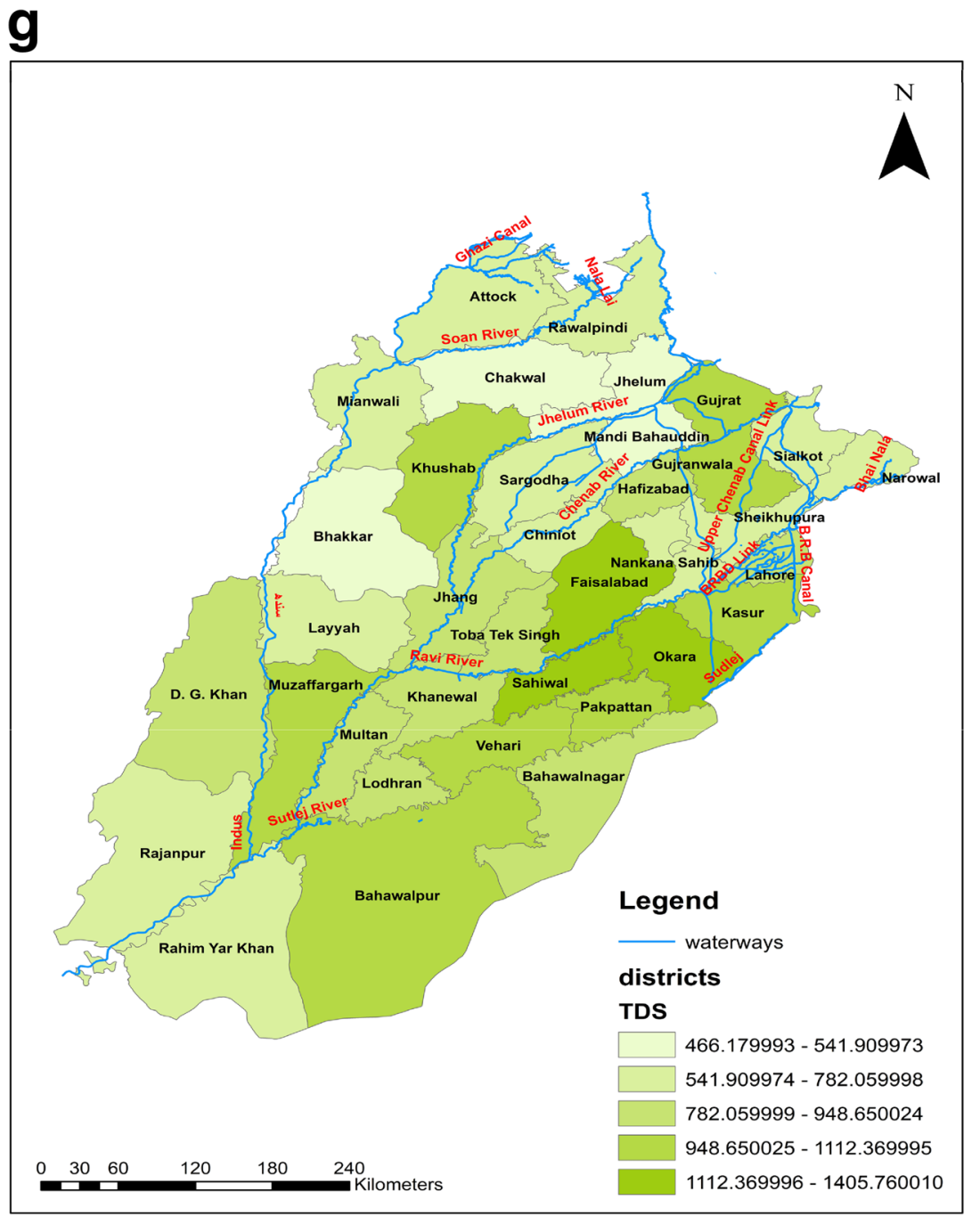

Fig. 2 (continued)

Table 1 Summary of groundwater quality variables of 46,457 samples at Punjab level

\begin{tabular}{lrrrrrrr}
\hline Statistical parameter & \multicolumn{1}{l}{ TDS } & \multicolumn{1}{l}{$\mathrm{F}^{-}$} & $\mathrm{Fe}$ & $\mathrm{NO}_{3}{ }^{-}$ & $\mathrm{NO}_{2}^{-}$ & $\mathrm{pH}$ \\
\hline Mean & 862.67 & 12.83 & 0.74 & 0.13 & 9.93 & 0.82 & 7.59 \\
Median & 700.00 & 5.00 & 0.52 & 0.04 & 0.00 & 0.00 & 7.50 \\
Mode & 560.00 & 0.00 & 0.00 & 0.00 & 0.00 & 0.00 & 7.40 \\
Standard deviation & 715.07 & 25.39 & 1.99 & 0.35 & 26.14 & 19.74 & 0.54 \\
Sample variance & $511,324.27$ & 644.43 & 3.96 & 0.12 & 683.21 & 389.79 & 0.29 \\
Kurtosis & 623.90 & 89.89 & 2023.42 & 4790.67 & 2061.17 & $20,742.12$ & 17.17 \\
Skewness & 11.73 & 6.44 & 41.78 & 48.86 & 26.88 & 136.22 & -0.90 \\
Max & $52,360.00$ & 735.00 & 121.00 & 37.20 & 2215.00 & 3033.00 & 10.90 \\
Min & 50.00 & 0.00 & 0.00 & 0.00 & 0.00 & 0.00 & 0.09 \\
\hline
\end{tabular}

Bahawalnagar or Bahawalpur might be due to stoppage of recharge from Rivers Ravi and Sutlej, intrusion of salty groundwater from Rajasthan [84, 85], industrial drain which stretches from Kasur along the Indian border up to the Arabian sea. Most districts of non-saline (mean data) have hard rock, confined aquifer [47], continuous recharging from rain, less industrial density (Figs. 2 and 3 in supporting information) and less agriculture pollution as compared to classes 1 and 3 of mean data (Tables 3 and 4). 
Table 2 Correlation of socioeconomic factors with water quality parameters
Table 3 HCA-based class centroid for each variable

\begin{tabular}{lrrrrrrr}
\hline Dependent variable & \multicolumn{1}{l}{ TDS } & \multicolumn{1}{l}{ As } & \multicolumn{1}{l}{$\mathrm{F}^{-}$} & $\mathrm{Fe}$ & $\mathrm{NO}_{3}{ }^{-}$ & $\mathrm{NO}_{2}{ }^{-}$ & $\mathrm{pH}$ \\
\hline Rain $(\mathrm{mm})$ & -0.28 & -0.22 & 0.17 & 0.10 & 0.24 & 0.30 & -0.27 \\
Industrial density $\left(\# / \mathrm{km}^{2}\right)$ & 0.40 & 0.33 & -0.02 & 0.00 & 0.31 & -0.10 & 0.06 \\
Tube well density $\left(\# / \mathrm{km}^{2}\right)$ & -0.04 & 0.05 & 0.39 & 0.08 & 0.36 & 0.27 & -0.37 \\
Human population density $\left(\# / \mathrm{km}^{2}\right)$ & 0.19 & 0.38 & 0.04 & 0.00 & 0.19 & -0.07 & 0.05 \\
Animal population density $\left(\# / \mathrm{km}^{2}\right)$ & 0.24 & 0.31 & -0.03 & 0.16 & 0.12 & -0.11 & -0.04 \\
Fertilizer density $\left(\times 1000\right.$ ton $\left./ \mathrm{km}^{2}\right)$ & 0.53 & 0.40 & 0.18 & 0.31 & 0.06 & -0.02 & -0.04
\end{tabular}

\begin{tabular}{llllllll}
\hline Class & TDS & \multicolumn{1}{l}{$\mathrm{As}$} & $\mathrm{F}$ & $\mathrm{Fe}$ & $\mathrm{NO}_{3}{ }^{-}$ & $\mathrm{NO}_{2}^{-}$ & $\mathrm{pH}$ \\
\hline 1 & 987.543 & 13.679 & 0.790 & 0.213 & 10.535 & 0.641 & 7.610 \\
2 & 651.794 & 8.836 & 0.882 & 0.164 & 14.627 & 8.201 & 7.499 \\
3 & 1358.873 & 11.787 & 0.873 & 0.143 & 25.218 & 0.663 & 7.982 \\
\hline
\end{tabular}

Table 4 Distribution of Punjab districts into three classes determined through HCA

\begin{tabular}{ll}
\hline Class & District \\
\hline 1 & Bahawalpur, Bahawalnagar, Khanewal, \\
& Lodhran, Multan, Muzafar Garh, Vehari, DG \\
& Khan, Lahore, Kasur, Pakpattan, Sahiwal, \\
& Jhang, Khushab, Gujranwala, Gujrat, \\
& Hafizabad \\
& Attock, Mianwali, Bhakar, Layya, R-Y-Khan, \\
& Rajanpur, Rawalpindi, Chakwal, Jehlam, \\
& MB-Din, Sargodha, Chiniot, Sheikhupura, \\
& Nankana Sahib, Narowal, Sialkot, TT Singh \\
& Faisalabad, Okara \\
\hline
\end{tabular}

The most polluted Faisalabad district has single unconfined aquifer with alluvial deposits [47]. It consists of sand, silt, silty clay, and cankers. Down to Okara, near Harappa, Bari Doab has sandy aquifer. Hard rock is not present in Bari Doab; rather, coarse sand is common [86]. In the Thal, Bari, and Rechna Doab, water level rose after Indus water irrigation canals system was introduced in 1912 and it contributed to increase in the level up to 1960; from 1960 onward, government decided to increase tube well irrigation because of higher crop intensity [86], but it leads to higher water TDS due to possible water mining pressure $[87,88]$. Water table of lower part of Bari Doab has current depletion rate of $0.55 \mathrm{~m}$ in contrary to upper part (Balloki \& Okara) that has stable water table due to lower Bari Doab canal (LBDC) \& higher Rain [86]. Bari Doab has more

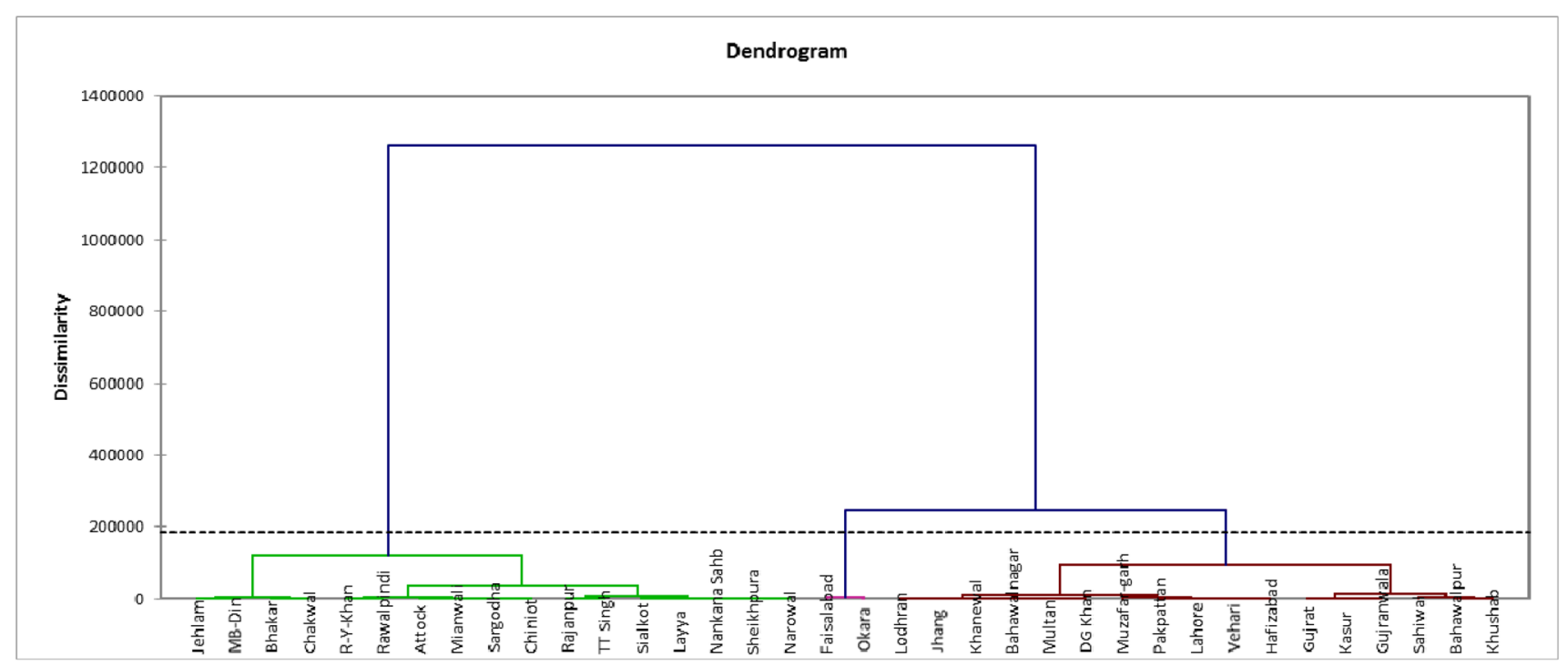

Fig. 3 Dendrogram shows three classes of groundwater: northwestern districts (green), central (pink), and southeastern districts (maroon) 
Table 5 Eigenvalue, variability, and cumulative \% of each extracted component through PCA

\begin{tabular}{lrrrrr}
\hline & F1 & \multicolumn{1}{c}{ F2 } & \multicolumn{1}{c}{ F3 } & \multicolumn{1}{c}{ F4 } & \multicolumn{1}{c}{ F5 } \\
\hline Eigenvalue & 1.90 & 1.40 & 1.11 & 1.03 & 0.89 \\
Variability (\%) & 30.21 & 23.12 & 20.25 & 17.14 & 6.21 \\
Cumulative \% & 30.21 & 53.33 & 73.58 & 90.72 & 96.93 \\
\hline
\end{tabular}

industries and less rain in lower part; that is why, water is more deteriorated in this region than northwest.

\subsection{PCA}

Principal component analysis (PCA) discovered 4 principal components based on Kaiser's criterion (Table 5). Only 4 components have eigenvalue greater than 1 and contribute $90.72 \%$ of cumulative $\%$ variability. Principal component analysis found all ions positively correlated with TDS except $\mathrm{NO}_{2}^{-}$(Table 6). Weak correlations values of TDS versus other pollutants suggest major contribution in TDS might be due to $\mathrm{Na}^{+}, \mathrm{Mg}^{2+}, \mathrm{K}^{+}, \mathrm{SO}_{4}{ }^{2-}, \mathrm{HCO}_{3}{ }^{-}$, and $\mathrm{Cl}^{-}[60,89,90]$; pesticides and dyes products in Faisalabad or meteoric conditions [91]. Angle between PCA variables shows (as shown by red dot in Fig. 4a) TDS and $\mathrm{NO}_{2}{ }^{-}$are negatively correlated as angle $\sim 180^{\circ}$ while $\mathrm{As}, \mathrm{NO}_{3}{ }^{-}, \mathrm{Fe}$, and TDS are positively correlated as angle $<90^{\circ}$; Fe and $\mathrm{NO}_{2}{ }^{-}$are not correlated as angle $\sim 90^{\circ}$.

The first component (F1) with eigenvalue of 1.90 accounts for $30.21 \%$ of the total variability due to rain or water streams recharge. Positive loading of all ions and TDS in F1 (Table 7) shows same direction except $\mathrm{NO}_{2}{ }^{-}$[90]. All variables have lower values than TDS, showing TDS has more variability than $\mathrm{As}, \mathrm{Fe}, \mathrm{NO}_{3}{ }^{-}$in $\mathrm{F} 1$ direction. Districts with high rainfall, Indus River path, Mangla and Chasma Lake are present in left side (Fig. 4a) and bottom quadrants
Table 6 Pearson correlation coefficient determined through PCA

\begin{tabular}{lllllllll}
\hline Variables & $\mathrm{TDS}$ & $\mathrm{As}$ & $\mathrm{F}^{-}$ & $\mathrm{Fe}$ & $\mathrm{NO}_{3}{ }^{-}$ & $\mathrm{NO}_{2}{ }^{-}$ & $\mathrm{pH}$ & Depth \\
\hline TDS & 1 & 0.26 & 0.06 & 0.24 & 0.11 & -0.38 & 0.32 & -0.276 \\
$\mathrm{As}$ & 0.26 & 1 & -0.02 & -0.01 & 0.14 & -0.28 & -0.15 & -0.112 \\
$\mathrm{~F}$ & 0.06 & -0.02 & 1 & -0.02 & -0.14 & -0.04 & -0.00 & -0.042 \\
$\mathrm{Fe}$ & 0.24 & -0.01 & -0.02 & 1 & 0.22 & -0.01 & -0.16 & 0.089 \\
$\mathrm{NO}_{3}{ }^{-}$ & 0.11 & 0.14 & -0.14 & 0.22 & 1 & -0.21 & -0.06 & -0.037 \\
$\mathrm{NO}_{2}{ }^{-}$ & -0.38 & -0.28 & -0.04 & -0.01 & -0.21 & 1 & -0.31 & 0.021 \\
$\mathrm{pH}^{-}$ & 0.32 & -0.15 & -0.00 & -0.16 & -0.06 & -0.31 & 1 & -0.046 \\
Depth & -0.28 & -0.11 & -0.04 & 0.09 & -0.04 & 0.02 & -0.05 & 1 \\
\hline
\end{tabular}

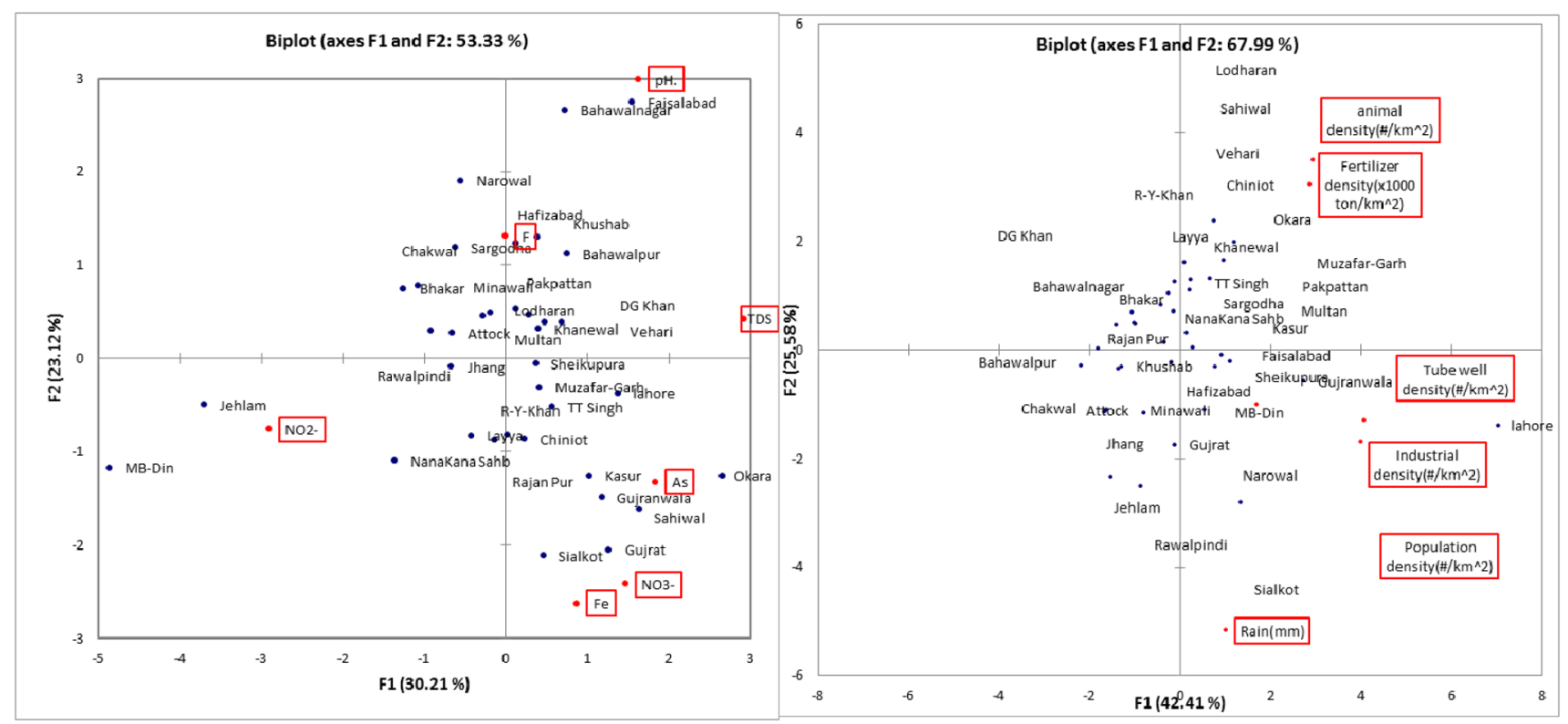

Fig. 4 Distribution of various districts based on their factor values. a Distribution based on water quality parameters (left); $\mathbf{b}$ distribution based on socioeconomic factors and rain (right) 
Table 7 Factor loading after varimax rotation determined by PCA

\begin{tabular}{lrrrr}
\hline & \multicolumn{1}{l}{ F1 } & \multicolumn{1}{l}{ F2 } & \multicolumn{1}{l}{ F3 } & \multicolumn{1}{l}{ F4 } \\
\hline TDS & 0.78 & 0.09 & 0.09 & 0.25 \\
$\mathrm{As}$ & 0.49 & -0.31 & 0.48 & -0.55 \\
$\mathrm{~F}$ & 0.00 & 0.30 & 0.74 & 0.404 \\
$\mathrm{Fe}$ & 0.23 & -0.61 & -0.01 & 0.66 \\
$\mathrm{NO}_{3}{ }^{-}$ & 0.39 & -0.56 & -0.33 & -0.021 \\
$\mathrm{NO}_{2}^{-}$ & -0.77 & -0.17 & 0.00 & 0.17 \\
$\mathrm{pH}^{-}$ & 0.43 & 0.69 & -0.40 & 0.146 \\
\hline
\end{tabular}

(4b); same districts with less rain and less river recharge are located in right side (Fig. 4a) and top two quadrants (Fig. 4b).

$\mathrm{F} 2$ with eigenvalue of 1.40 has negative loading of $\mathrm{Fe}$, As, $\mathrm{NO}_{3}{ }^{-}$, and $\mathrm{NO}_{2}{ }^{-}$, while it has positive loading of $\mathrm{pH}$ and $\mathrm{F}^{-}$(Fig. 4a, Table 7). Fertilizer consumption is increased from one million ton to three million tons since 1980 to 2007 [11]; therefore, it is possible that F2 is related to pollution sources like industries, fertilizers, population, and maneuvers. It shows As, $\mathrm{Fe}$, and $\mathrm{NO}_{3}{ }^{-}$(Fig. 4a) can be due to anthropogenic source, e.g., fertilizers, sewage, and other pollution sources [11]. F2 has major contribution from industrial activities as all industrial cities vary along vertical axis in Fig. 4a and b, as Faisalabad is at the top (Fig. 4a). Shallow hand pumps water has more nitrate contamination than deep boring; this is due to fertilizer seepage of $\mathrm{NO}_{3}{ }^{-}$and As [11]. Negative charge of $\mathrm{NO}_{3}{ }^{-}$and porous soil of Punjab lead to higher permeability to groundwater from agriculture source [77].

Samples in upper right quadrant (Fig. 4a) are enriched with TDS, $\mathrm{F}^{-}$and $\mathrm{pH}$; those in lower-right quadrant are enriched with $\mathrm{NO}_{3}{ }^{-}, \mathrm{Fe}$ and As. Those in lower-left quadrant are enriched with $\mathrm{NO}_{2}^{-}$. Slight-saline to saline districts with worse quality appear in right quadrant (Fig. 4a) and severity increases to the extreme right (Fig. 4a). Faisalabad and Bahawalpur are at top right quadrant due to TDS, while Okara has significant TDS, As, $\mathrm{Fe}$, and $\mathrm{NO}_{3}{ }^{-}$contribution. Districts with non-saline groundwater appear in left quadrant, while quality increases to the extreme left, except $\mathrm{NO}_{2}{ }^{-}$pollution that also increases in the extreme left (Fig. 4a). Higher $\mathrm{NO}_{2}{ }^{-}$in Jehlam \& MB-Din might be due to water logging. Districts with medium level salinity and trace elements contamination (Chiniot, Sialkot, Hafizabad) fall in center of the line (Fig. 4a). Districts with higher pollutants in Fig. 4a are same with higher socioeconomic activities in top-right quadrant of Fig. 4b. Districts with less pollutants in left side of Fig. 4a are similar with higher rain in Fig. 4b (bottom-right).

F3 with eigenvalue 1.11 (Fig. 4a) has negative loading (Table 7) of $\mathrm{pH}$ and nitrate, while $\mathrm{As}$ and $\mathrm{F}^{-}$have positive loading (Fig. 4 in supporting information). F3 has positive loading of As and $\mathrm{F}^{-}$which might be due to anthropogenic source (fertilizers contain $\mathrm{F}^{-} \sim 53-255 \mathrm{mg} / \mathrm{Kg}$, As $\sim 5-10 \mathrm{mg} / \mathrm{Kg}$ [28]. F4 with eigenvalue of 1.04 shows $\mathrm{F}^{-}$and $\mathrm{Fe}$ also contribute to TDS from geological origin [2, 10]. F4 shows TDS, F, and Fe have same source and As may due to other sources $[12,16]$.

A study in the Tharparkar reported TDS $937-7690 \mathrm{mg} / \mathrm{L}$, while $\mathrm{Na}^{+}, \mathrm{K}^{+}, \mathrm{Ca}^{2+}, \mathrm{Mg}^{2+}, \mathrm{Fe}$ were found to be $166-2180$, 8.16-22.3, 26.9-482, 48.9-207, and 0.109-0.327 mg/L, respectively. Brahman argued high $\mathrm{As}$ and $\mathrm{F}^{-}$may be due to complex geochemical factors, including geological factors, climatic effect and agriculture pollution using principal component analysis [58]. Arsenic and fluoride are contributed by pesticide, fertilizers, hydrofluorocarbon, and water abstraction [18, 21]. Hydroxyapatite mineral releases $\mathrm{As}$ in high-alkaline water, while $\mathrm{F}^{-}$is enriched in alkaline environment, minerals weathering, fluorite dissolution, dolomite dissolution, and arid conditions [11, 13]. Urea fertilizer contributes to $\mathrm{NO}_{3}{ }^{-}$and $\mathrm{NO}_{2}{ }^{-}$pollution in addition to animal waste [28]. Tube well abstraction also increases TDS levels in addition to sewage waste $[28,30]$. Most vulnerable Bari Doab districts groundwater recharge is severally reduced, as Ravi and Sutlej Rivers have been dried [12]. Published literature and current study proves pollution is enhanced by socioeconomic sources.

\subsection{Spatial variation in TDS}

Current studies found 8 districts out of 36 districts have mean TDS $>1000 \mathrm{mg} / \mathrm{L}$ (Fig. 2g, Tables 1, 2, and 3 in supporting information). These are Faisalabad ( $1405.76 \mathrm{mg} / \mathrm{L})$, Gujranwala (1063.96), Okara (1311.99 mg/L), Sahiwal (1188.48 mg/L), Kasur (1041.39 mg/L), Bahawalpur (1105.38 mg/L), Khushab (1112.37 mg/L), and Gujrat $(1011.70 \mathrm{mg} / \mathrm{L})$. Four out of 8 districts are industrial cities (Faisalabad, Gujranwala, Kasur, and Gujrat), while Okara, Sahiwal, Bahawalpur are agriculture districts, and Khushab is an agriculture and mining hub (Fig. 2 in supporting information).

Districts with mean TDS $751-1000 \mathrm{mg} / \mathrm{L}$ are considered at threat level because majority samples of these districts have TDS $>1000 \mathrm{mg} / \mathrm{L}$. Eight districts of this group fall in $900-1000 \mathrm{mg} / \mathrm{L}$ range. These are Lahore ( $948.65 \mathrm{mg} / \mathrm{L})$, Hafizabad $(946.50 \mathrm{mg} / \mathrm{L})$, Bahawalnagar (920 mg/L), Pakpattan ( $969.84 \mathrm{mg} / \mathrm{L})$, Vehari $(972.86 \mathrm{mg} / \mathrm{L})$, Khanewal (909.58 mg/L), DG Khan (922.34 mg/L), Multan (929.34 mg/L), and Muzafar Garh $(994.74 \mathrm{mg} / \mathrm{L})$, while Lodhran $(874.85 \mathrm{mg} / \mathrm{L})$, Jhang $(876.27 \mathrm{mg} / \mathrm{L})$, TT Singh (811.56 mg/L), and Rajanpur (782.06 mg/L) also lie in slight saline range (751-1000 $\mathrm{mg} / \mathrm{L})$.

The districts which have TDS $501-750 \mathrm{mg} / \mathrm{L}$ are relatively safe; these are Attock ( $656.45 \mathrm{mg} / \mathrm{L})$, Rawalpindi $(614.74 \mathrm{mg} / \mathrm{L})$, Chiniot $(655.51 \mathrm{mg} / \mathrm{L})$, Mianwali 


\section{Faisalabad}

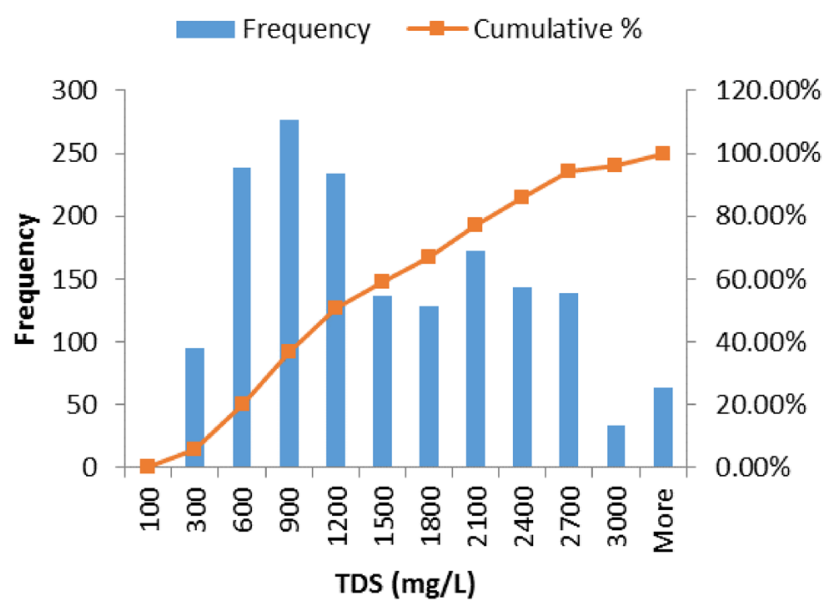

Fig. 5 Two-hump TDS distribution shows contribution of two different types of groundwater in Faisalabad

(682.90 mg/L), Sargodha (644.55 mg/L), and Nankana Sahib (711.64 mg/L), Sheikhupura (720.02 mg/L), Sialkot (734.56 mg/L), Narowal (738.89 mg/L), and Bhakar ( $541.91 \mathrm{mg} / \mathrm{L}$ ). These districts have high rainfall or Indus/ Chenab/Jehlam recharge and less industry. The completely safe districts have $\leq 500 \mathrm{mg} / \mathrm{L}$; these are Chakwal $(466.18 \mathrm{mg} / \mathrm{L})$, Jehlam (495.83 mg/L), and MB-Din $(500.37 \mathrm{mg} / \mathrm{L})$. Complete safe districts are part of Pothwar confined aquifer, high rainfall, Mangla lake, and Jehlam River recharge.

Faisalabad mode and median TDS are $2439 \mathrm{mg} / \mathrm{L}$ and $1179.50 \mathrm{mg} / \mathrm{L}$, while mean value is $1405.76 \mathrm{mg} / \mathrm{L}$. These data prove there is no particular site in Faisalabad which increases the mean value; rather, most of the sites have higher TDS and it falls into severe saline due to mode value. TDS distribution shows two humps (Fig. 5), the median of first hump is at $950 \mathrm{mg} / \mathrm{L}$, while second hump median is formed at $2150 \mathrm{mg} / \mathrm{L}$. These two humps are representative of rural and urban groundwater quality. The higher TDS hump has industrial, urbanization, and sewage contribution; however, $950 \mathrm{mg} / \mathrm{L}$ hump has agriculture pollution and evaporation base seepage.

Okara district mode and median TDS are $1435 \mathrm{mg} / \mathrm{L}$ and $980 \mathrm{mg} / \mathrm{L}$, respectively, while it has single hump histogram. Histogram shows Okara does not have any urban/ rural significant difference and higher TDS is due to agriculture industry. Okara lies in middle of the Bari Doab, and it is agriculture district and has the highest number of tube wells [92]. The next geographical neighbor of Okara is Sahiwal, and it follows similar trend to Okara in all aspects as its mean, median, and mode are 1188.48, 1010.50 , and $924.00 \mathrm{mg} / \mathrm{L}$, respectively with single hump histogram. The median of (Rural) Faisalabad, Okara, and Sahiwal is $950 \mathrm{mg} / \mathrm{L}, 980 \mathrm{mg} / \mathrm{L}$, and $1010.5 \mathrm{mg} / \mathrm{L}$, respectively. The median values are very close, and these districts are geographically connected to each other; it is possible agriculture activities are dominating reasons of TDS, while stoppage of fresh water recharge from two rivers due to Indus water treaty is setting new baseline of groundwater quality. Agriculture streams in Punjab were cemented during 2002-2008 which might have decreased water recharge that can be one of the reasons behind higher TDS at micro-level; however, proper investigation is required. The eastern neighbor of Okara is Kasur whose mean, median, and mode TDS are 1041.39, 815.50, and $700 \mathrm{mg} / \mathrm{L}$, respectively. Median and mode of Kasur are less than Okara; therefore, it is expected that certain locations are polluted and mean value is increased; however, most sites are safe (mode $700 \mathrm{mg} / \mathrm{L}$ ). Due to small tube wells, BRB and UC link-canals, recharge is enough and TDS is $<1000 \mathrm{mg} / \mathrm{L}$. Pakpattan has mode value of TDS $1177 \mathrm{mg} / \mathrm{L}$, while its median and mean are 885 and $969.84 \mathrm{mg} / \mathrm{L}$, while Sahiwal and Faisalabad neighboring TT Singh mode is $1019 \mathrm{mg} / \mathrm{L}$, higher than WHO, while its mean and median are 811.56 and $574 \mathrm{mg} / \mathrm{L}$. Gujranwala, Faisalabad, Okara, Pakpattan, Layya, and TT Singh follow trend of Mode $>$ Mean $>$ Median.

Most of the south Punjab districts (Sahiwal, Bahawalpur, Bahawalnagar, DG-Khan, Khanewal, Multan, Lodhran, Muzaffargarh, Rajanpur), Kasur, Nankana Sahib, Sialkot, Mianwali, follow trend of mean $>$ median $>$ mode. Skewness of all districts is positive (positively skewed, skewness $\sim 1-1988$ ) which shows uneven distribution due to contaminations at higher side.

Indus water passes from Attock, Mianwali, Bhakar, Muzafar Garh, and R. Y. Khan; the mean TDS in most of the districts is below 700 except Muzafar Garh (mean TDS 994.71); mode of Muzafar Garh is also $450 \mathrm{mg} / \mathrm{L}$; hence, the data show proper recharge of groundwater in these districts. TDS of current study shares many common features with already published data [10] which proves the validity of current findings. The remaining districts: Jhang, Vehari, R-Y-Khan follow Mean $>$ Mode $>$ Median.

Based on nonlinear predictive modeling, Eq. (2) was derived which predicts TDS for given values of trace pollutants. It is nonlinear multiple regression model and explains $70 \%$ variance in TDS at Punjab provincial level under current recharge conditions.

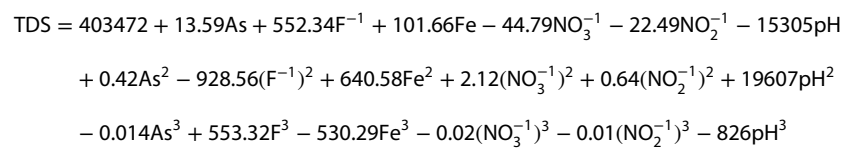




\subsection{Water quality model with respect to socioeconomic parameters}

Rain, river, and canal recharge improve water quality, while industrial effluents, water abstraction, agriculture fertilizers, pesticides, animal density, human population, and urban sewage dumps deteriorate the water quality. Soil type can affect groundwater quality. Correlation between TDS and socioeconomic factors shows influence of each factor on groundwater quality (Table 2 ).

\subsubsection{Soil, agriculture, industrial activities}

Punjab is divided into five different soil types (Table 8), Sind Sagar Doab has two different types of soil, and right bank of Indus after Panjnad is different. Jech, Rechna, and Bari Doab have Loamy, clayey, non-calcareous soil, while left bank of Sutlej also has sandy soil. Water mining in shallow water tables and permeable soil induces groundwater recharge $[2,10]$ by producing significant vertical head [93]. Therefore, it is also expected that soil combined with tube well abstraction in center and southeast Punjab has severally affected shallow groundwater. In addition, agriculture activities and pollutants are higher in southeast and center Punjab (Fig. 4). Correlation of 0.40 was found between TDS and industries while 0.53 between TDS and fertilizes. Industry is also higher in center and southeast Punjab (Fig. 2 in supporting information) and contributes to more contaminations. Indus water canal Irrigation system was designed for cropping intensity of $67 \%$ which has steadily increased to $160 \%$ at present level [86]. Increase of groundwater irrigation leaves salt deposit due to high temperature climate in the center and southeast Punjab. Increase in temperature increases evaporation in lower Bari Doab \& south Punjab districts [94], and later irrigation increases seepage to groundwater $[2,10]$.

\subsubsection{Seepage, recharge, and rain}

Rain recharge is dominated if rainfall $>1000 \mathrm{~mm}$; if rainfall is $\sim 500-1000 \mathrm{~mm}$, recharge is likely to be met by canal leakage and rainfall. If rainfall occurs $<500 \mathrm{~mm}$, recharge is dominated by irrigation returns and canal leakage [2]. Rainfall decreases gradually north to south, as Lahore, Faisalabad, and Multan have 710, 370, and $200 \mathrm{~mm}$ of rain, respectively (Fig. 3 in supporting information), while TDS is inversely correlated with rain having -0.28 of correlation coefficient (Table 2). Average rainfall in north Punjab (Jehlam, Sialkot, Narowal, and Lahore) is $900-1000 \mathrm{~mm}$; moreover, link canals also add to recharge. South Punjab (Multan, Lodhran, Muzafar Garh, and surrounding) has annual rainfall $\sim 150-200 \mathrm{~mm}$. Therefore, it is concluded that center and south Punjab [95] recharge is only through link canals and rivers. Two rivers have (Ravi and Sutlej) have dried, and therefore, only recharge is due to small leftover water of Trimmu and Indus. Muzafar Garh may have salinity of shallow water due to overcharging from Indus, Taunsa-Panjnad link canal, and Jehlam-Chenab-Ravi-Sutlej (JCRS) combined stream. North side has generally rain recharge, while west side is recharged by Indus.

Influence of socioeconomic factors and rain was modeled for TDS as these affect groundwater quality. A nonlinear model explains $57 \%$ variance in TDS using rain, industrial, tube wells, human population, animal population, and fertilizer density as independent variables. Remaining variance might be due to pesticides, geological factors or other socioeconomic activities. Equation (3) can predict

Table 8 Types and characteristics of Punjab soil [96]

\begin{tabular}{|c|c|c|c|}
\hline Regions & Districts & Soil composition & Activity \\
\hline Pothohar & Rawalpindi, Jehlam, Attock, Chakwal & $\begin{array}{l}\text { Loam, loess and residual, shallow loamy } \\
\text { gravelly, rocks of plateau and mountain. } \\
\text { Deep water }\end{array}$ & Arid agriculture \\
\hline Thal desert & $\begin{array}{l}\text { Part of Khushab, Bhakkar, Layya, Muzafar Garh, } \\
\text { and Mianwali }\end{array}$ & Sandy & Arid \& flood agriculture \\
\hline Fertile Indus plain & Central, south, northeast Punjab & $\begin{array}{l}\text { Loamy, clayey of old flood plain, clayey non- } \\
\text { calcareous of old terrace }\end{array}$ & Flood agriculture \\
\hline Plain to plateau & Rajanpur, DG-Khan & $\begin{array}{l}\text { Sandy loamy silt of piedmont plains, shal- } \\
\text { low loamy gravelly sol, rock of plateau and } \\
\text { mountain }\end{array}$ & Flood agriculture \\
\hline Cholistan desert & $\begin{array}{l}\text { Bahawalpur, Part of R-Y-Khan and Bahawal- } \\
\text { nagar }\end{array}$ & Sandy & Arid \& flood agriculture \\
\hline
\end{tabular}


any change in TDS due to all possible factors until the river recharge remains at current level.

$$
\begin{aligned}
\text { TDS }= & 916+0.42 R-2390 I+22 T+0.54 P \\
& -5266 A+37035 F-2.6 \times 10^{-4} R^{2}+13432 I^{2} \\
& -3.58 T^{2}-3.5 \times 10^{-4} P^{2}+19027 A^{2}-1987977 F^{2} \\
& -4.37 e^{-7} R^{3}-1.61 \times 10^{4} I^{3}+0.1 T^{3}+1.24 e^{-7} P^{3} \\
& -22062 A^{3}+3019 e^{4} F^{3}
\end{aligned}
$$

where $R=$ Rain, $I=$ industrial density, $T=$ tube well density, $P=$ population density, $A=$ animal density, $\mathrm{F}=$ fertilizer sale density (fertilizer sale per square kilometer of the area).

\section{Conclusions}

Various parameters exceed WHO safe limits, as they were found to be $26 \%$ of TDS, $8.07 \%$ of As, $10.63 \%$ of $\mathrm{F}^{-}, 1 \%$ of $\mathrm{Fe}, 1.33 \%$ of $\mathrm{NO}_{3}^{-}$, and $0.92 \%$ of $\mathrm{NO}_{2}{ }^{-}$. Punjab was dissected into northwest and southeast based on its groundwater quality. Northwest has better quality due to rain and river recharge, and southeast (along India border) has deteriorated quality due to less rain, less river recharge, and higher socioeconomic activities. Faisalabad and Okara have worst salinity in the region. PCA suggested agriculture and industry are dominantly increasing TDS, while river and rain recharge are decreasing TDS. Therefore, it is concluded that Indus water treaty has changed the water quality in addition to industrialization, agriculture, and population, farming and rain. The following points can be concluded from the current study:

- Geology of (Indian and Pakistani) Punjab is similar, and deterioration in groundwater quality of one can affect the neighboring Punjab.

- Water quality can be improved by careful planning crops intensity, controlling water abstraction, flood irrigation, industrial pollution, and fertilizer consumption.

- Canal water should be provided for agriculture, and north-south canals should be constructed for recharge.

- Canals should be belt from Trimmu passing from Khanewal, Lodhran, Multan, Vehari, and Bahawalpur. Canal should be belt at Kalabagh, passing from Khushab, Jhang \& TT-Singh. A canal should be belt from Chenab to Ravi, passing from Faisalabad, Sahiwal, Vehari, and Pakpattan ending at Bahawalnagar. Water should be managed from other link canals and rivers for new canals.

- Indus water treaty should be re-negotiated between India and Pakistan to increase water in Ravi and Sutlej for conservation of the environment.
Acknowledgements The authors are deeply thankful to the research funding provided by Government of the Punjab for collection and chemical analysis of the samples. We are also thankful to DG PINSTECH for providing financial assistance for analysis and interpretation of the data as well as manuscript's preparation. We are also thankful to M. Rafiq Sheikh for suggestions and improvement in the manuscript. We are thankful to Dr. Dilaband, Masud Ahmad, Dr. Qazi Qasim, and Mr. Munib Ahmad for their moral support in this work.

\section{Compliance with ethical standards}

Conflict of interest All authors declare that they have no conflict of interest.

\section{References}

1. Bennett GD, Sheikh IA, Alr S (1967) Analysis of aquifer tests in the Punjab region of West Pakistan. USGPO, Washington, D.C.

2. Bonsor HC, MacDonald AM, Ahmed KM et al (2017) Hydrogeological typologies of the Indo-Gangetic basin alluvial aquifer, south Asia. Hydrogeol J 25:1377-1406. https://doi.org/10.1007/ s10040-017-1550-z

3. Chen J, Li J, Zhang Z, Ni S (2014) Long-term groundwater variations in northwest India from satellite gravity measurements. Glob Planet Change. https://doi.org/10.1016/j.glopl acha.2014.02.007

4. Rodell M, Velicogna I, Famiglietti JS (2009) Satellite-based estimates of groundwater depletion in India. Nature. https://doi. org/10.1038/nature08238

5. Tiwari VM, Wahr J, Swenson S (2009) Dwindling groundwater resources in northern India, from satellite gravity observations. Geophys Res Lett. https://doi.org/10.1029/2009GL039401

6. Quereshi AS, Gill MASA (2008) Sustainable groundwater management in Pakistan: challenges and opportunities. Irrig Drain 59:107-116

7. British Geological Survey and Department of Public Health Engineering (BGS and DPHE) (2001) Arsenic contamination of groundwater in Bangladesh

8. Central Groundwater Board (CGWB) (2010) groundwater quality in shallow aquifers of India. New Delhi

9. Bajwa BS, Kumar S, Singh S et al (2017) Uranium and other heavy toxic elements distribution in the drinking water samples of SW-Punjab, India. J Radiat Res Appl Sci 10:13-19. https://doi. org/10.1016/j.jrras.2015.01.002

10. MacDonald AM, Bonsor HC, Ahmed KM et al (2016) Groundwater quality and depletion in the Indo-Gangetic basin mapped from in situ observations. Nat Geosci 9:762-766. https://doi. org/10.1038/ngeo2791

11. Tahir MA, Rasheed $H$ (2008) Distribution of nitrate in the water resources of Pakistan. Afr J Environ Sci Technol 2:397-403. https ://doi.org/10.4314/ajest.v2i11

12. Younas A, Mushtaq N, Khattak JA et al (2019) High levels of fluoride contamination in groundwater of the semi-arid alluvial aquifers, Pakistan: evaluating the recharge sources and geochemical identification via stable isotopes and other major elemental data. Environ Sci Pollut Res 26:35728-35741

13. Van Geen A, Farooqi A, Kumar A et al (2019) Field testing of over 30,000 wells for arsenic across 400 villages of the Punjab plains of Pakistan and India: implications for prioritizing mitigation. Sci Total Environ 654:1358-1363. https://doi.org/10.1016/j.scito tenv.2018.11.201

14. Mahar MT, Khuhawar MY, Jahangir TM, Baloch MA (2015) Determination of arsenic contents in groundwater of district Rahim 
Yar Khan Southern Punjab. Pakistan. Arab J Geosci. https://doi. org/10.1007/s12517-015-1979-0

15. Arshad N, Imran S (2017) Assessment of arsenic, fluoride, bacteria, and other contaminants in drinking water sources for rural communities of Kasur and other districts in Punjab, Pakistan. Environ Sci Pollut Res 24:2449-2463. https://doi.org/10.1007/ s11356-016-7948-7

16. Raza M, Hussain F, Lee J-Y et al (2017) Groundwater status in Pakistan: A review of contamination, health risks, and potential needs. Crit Rev Environ Sci Technol 47:1713-1762

17. He X, Li P, Ji Y et al (2020) Groundwater arsenic and fluoride and associated arsenicosis and fluorosis in China: occurrence distribution and management. Expo Heal. https://doi.org/10.1007/ s12403-020-00347-8

18. Subba Rao N, Ravindra B, Wu J (2020) Geochemical and health risk evaluation of fluoride rich groundwater in Sattenapalle Region, Guntur district, Andhra Pradesh, India. Hum Ecol Risk Assess. https://doi.org/10.1080/10807039.2020.1741338

19. Adimalla N, Li P (2019) Occurrence, health risks, and geochemical mechanisms of fluoride and nitrate in groundwater of the rock-dominant semi-arid region, Telangana State, India. Hum Ecol Risk Assess 25:81-103. https://doi.org/10.1080/10807 039.2018.1480353

20. Malik A, Parvaiz A, Mushtaq N et al (2020) Characterization and role of derived dissolved organic matter on arsenic mobilization in alluvial aquifers of Punjab, Pakistan. Chemosphere 251:126374. https://doi.org/10.1016/j.chemosphere.2020.12637 4

21. Faroogi A, Masuda H, Firdous N (2007) Toxic fluoride and arsenic contaminated groundwater in the Lahore and Kasur districts, Punjab, Pakistan and possible contaminant sources. Environ Pollut 145:839-849. https://doi.org/10.1016/j.envpol.2006.05.007

22. Masuda H, Mitamura M, Farooqi AM et al (2010) Geologic structure and geochemical characteristics of sediments of fluoride and arsenic contaminated groundwater aquifer in Kalalanwala and its vicinity, Punjab, Pakistan. Geochem J 44:489-505. https ://doi.org/10.2343/geochemj.1.0098

23. Farooqi A, Masuda H, Siddiqui R, Naseem M (2009) Sources of arsenic and fluoride in highly contaminated soils causing groundwater contamination in Punjab, Pakistan. Arch Environ Contam Toxicol 56:693-706. https://doi.org/10.1007/s0024 4-008-9239-x

24. Ali W, Mushtaq N, Javed T et al (2019) Vertical mixing with return irrigation water the cause of arsenic enrichment in groundwater of district Larkana Sindh, Pakistan. Environ Pollut. https://doi. org/10.1016/j.envpol.2018.10.103

25. Ali W, Aslam MW, Junaid M et al (2019) Elucidating various geochemical mechanisms drive fluoride contamination in unconfined aquifers along the major rivers in Sindh and Punjab, Pakistan. Environ Pollut 249:535-549. https://doi.org/10.1016/j. envpol.2019.03.043

26. Li P, Qian H, Wu J et al (2014) Occurrence and hydrogeochemistry of fluoride in alluvial aquifer of Weihe River, China. Environ Earth Sci 71:3133-3145. https://doi.org/10.1007/s1266 5-013-2691-6

27. Li P, He X, Li Y, Xiang G (2019) Occurrence and health implication of fluoride in groundwater of loess aquifer in the Chinese Loess Plateau: a case study of tongchuan, northwest China. Expo Heal 11:95-107. https://doi.org/10.1007/s12403-018-0278-x

28. Farooqi A, Masuda H, Kusakabe M et al (2007) Distribution of highly arsenic and fluoride contaminated groundwater from east Punjab, Pakistan, and the controlling role of anthropogenic pollutants in the natural hydrological cycle. Geochem J 41:213-234. https://doi.org/10.2343/geochemj.41.213

29. Rasool A, Xiao T, Baig ZT et al (2015) Co-occurrence of arsenic and fluoride in the groundwater of Punjab, Pakistan: source discrimination and health risk assessment. Environ Sci Pollut Res 22:19729-19746. https://doi.org/10.1007/s11356-015-5159-2

30. Singh G, Rishi MS, Herojeet R et al (2020) Multivariate analysis and geochemical signatures of groundwater in the agricultural dominated taluks of Jalandhar district, Punjab. India J Geochem Explor 208:106395. https://doi.org/10.1016/j.gexplo.2019.10639 5

31. Hasan M, Shang Y, Akhter G, Khan M (2017) Geophysical investigation of fresh-saline water interface: a case study from south Punjab, Pakistan. Groundwater 55:841-856. https://doi. org/10.1111/gwat.12527

32. Wescoat JL, Siddiqi A, Muhammad A (2018) Socio-hydrology of channel flows in complex river basins: rivers, canals, and distributaries in Punjab, Pakistan. Water Resour Res 54:464-479. https://doi.org/10.1002/2017WR021486

33. Ward RJ, Greenman DW (1962) Hydrology and scientific reclamation in the Punjab, West Pakistan. US Government Printing Office, Washington, DC

34. Greenman DW, Bennett GD, Swarzenski WV (1967) Groundwater hydrology of the Punjab, west Pakistan, with emphasis on problems caused by canal irrigation. US Government Printing Office, Washington, D.C.

35. Khan HF, Yang YCE, Ringler $C$ et al (2016) Guiding groundwater policy in the Indus Basin of Pakistan using a physically based groundwater model. J Water Resour Plan Manag 143:05016014. https://doi.org/10.1061/(asce)wr.1943-5452.0000733

36. Moeen-ud-Din S (2009) Time-rate changes in groundwater levels and quality groundwater monitoring in Punjab. Lahore

37. Ahmad MN, Sultana R, Yoshida M, Salahuddin M (2020) Groundwater Contamination Issues in Chiniot Area, Punjab, Pakistan. Int J Environ Sci Dev 11:123-127. https://doi.org/10.18178/ijesd .2020.11.3.1237

38. Fau SY, Nasution Z, Hadi AJ (2019) Spatializing groundwater quality parameters and their impacts on land value in Khushab City, Punjab, Pakistan. Int J Econ Environ Geol 2:165. https://doi. org/10.1119/1.2218359

39. Shakeel M, Hussain T, Hussain M et al (2014) Distribution of total dissolved solids in drinking water by means of bayesian kriging and gaussian spatial predictive process. Water Qual Expo Heal 6:177-185. https://doi.org/10.1007/s12403-014-0123-9

40. France-Lanord C, Derry L, Michard A (2008) Evolution of the Himalaya since Miocene time: isotopic and sedimentological evidence from the Bengal Fan. Geol Soc London, Spec Publ. https://doi.org/10.1144/gsl.sp.1993.074.01.40

41. Ravi Kumar M, Mishra DC, Singh B (2013) Lithosphere, crust and basement ridges across Ganga and Indus basins and seismicity along the Himalayan front, India and Western Fold Belt, Pakistan. J Asian Earth Sci 75:126-140. https://doi.org/10.1016/j. jseaes.2013.07.004

42. Akram MS, Mirza K, Ali U, Zeeshan M (2019) Geotechnical and hydrological characterization of subsurface for metallic minerals mining operations in Punjab, Pakistan. Open J Geol 9:752-767

43. RIA Khan (2011) Water resource development in Pakistan. Presentation

44. Indus river. https://en.wikipedia.org/wiki//ndus_River

45. Facts KEY (2019) Irrigation system in Pakistan. https://waterinfo. net.pk/sites/default/files/knowledge/Irrigation System in Pakistan.pdf

46. Muhammad L, Muhammad SU, ljaz Ahad GM (2019) Water resources of Pakistan: demand, supply, and future challenges. In: Conference on water problems in Pakistan and their solutions. PNS, Islamabad, p 8

47. Steenbergen F van, Oliemans W (1997) Groundwater resource management in Pakistan. In: Proceedings of the Wageningen water workshop, pp 93-110 
48. Van Steenbergen F, Oliemans W (2002) A review of policies in groundwater management in Pakistan 1950-2000. Water policy 4:323-344

49. Amin $M$ (2005) Pakistan groundwater resources and it's sustainability. 705-WAPDA-House Lahore, Pakistan

50. Environment Protection Authority (Victoria) (EPA, Victoria) (2009) Sampling and analysis of waters, wastewaters soils and wastes. Ind water resource guidel

51. United States Environmental Protection Agency (2008) Handbook for developing watershed plans to restore and protect our waters. Washington, DC

52. Statistical Bureau of the Punjab (2018) Statistical pocket book of the Punjab. Lahore

53. Belkhiri L, Narany TS (2015) Using multivariate statistical analysis, geostatistical techniques and structural equation modeling to identify spatial variability of groundwater quality. Water Resour Manag. https://doi.org/10.1007/s11269-015-0929-7

54. Wu J, Li P, Qian H et al (2014) Using correlation and multivariate statistical analysis to identify hydrogeochemical processes affecting the major ion chemistry of waters: a case study in Laoheba phosphorite mine in Sichuan, China. Arab J Geosci 7:3973-3982. https://doi.org/10.1007/s12517-013-1057-4

55. Wu J, Li P, Wang D et al (2019) Statistical and multivariate statistical techniques to trace the sources and affecting factors of groundwater pollution in a rapidly growing city on the Chinese Loess Plateau. Hum Ecol Risk Assess. https://doi. org/10.1080/10807039.2019.1594156

56. Li P, Tian R, Liu R (2019) Solute geochemistry and multivariate analysis of water quality in the Guohua phosphorite mine, Guizhou Province, China. Expo Heal 11:81-94. https://doi. org/10.1007/s12403-018-0277-y

57. Chen K, Jiao JJ, Huang J, Huang R (2007) Multivariate statistical evaluation of trace elements in groundwater in a coastal area in Shenzhen, China. Environ Pollut 10:11-12. https://doi. org/10.1016/j.envpol.2006.09.002

58. Brahman KD, Kazi TG, Afridi $\mathrm{HI}$ et al (2013) Evaluation of high levels of fluoride, arsenic species and other physicochemical parameters in underground water of two sub districts of Tharparkar, Pakistan: a multivariate study. Water Res. https://doi. org/10.1016/j.watres.2012.10.042

59. Brahman KD, Kazi TG, Afridi HI et al (2013) Simultaneously evaluate the toxic levels of fluoride and arsenic species in underground water of Tharparkar and possible contaminant sources: a multivariate study. Ecotoxicol Environ Saf. https:// doi.org/10.1016/j.ecoenv.2012.11.023

60. Umar Kura N, Firuz Ramli M, Azmin Sulaiman WN et al (2013) Evaluation of factors influencing the groundwater chemistry in a small tropical Island of Malaysia. Int J Environ Res Public Health 10:1861-1881. https://doi.org/10.3390/ijerph10051861

61. Parish L, Guilford JP (2006) Fundamental statistics in psychology and education. Br J Educ Stud. https://doi.org/10.2307/3118885

62. Addinsoft (2019) Which statistical model should you choose? https://help.xlstat.com/customer/en/portal/articles/20624 61-what-statistical-model-should-i-choose-?b_id=9283. Accessed 27 May 2019

63. Stumpf MPH, Ingram PJ, Nouvel I, Wiuf C (2005) Statistical model selection methods applied to biological networks. Transactions on computational systems biology III. Springer, Berlin, pp 65-77

64. Shibata R (1989) Statistical aspects of model selection. From data to model. Springer, Berlin, pp 215-240

65. Guilford JP (1950) Fundamental statistics in psychology and education, 3rd edn. McGraw-Hill Education New York, UK

66. World Health Organization (1993) Guideline values for arsenic. WHO technical report series 776

67. World Health Organization (1994) Fluorides and oral health. WHO technical Report Series 846
68. World Health Organization (1996) Guidelines for drinking-water quality recommendations. WHO, Geneva

69. World Health Organization (1997) Guidelines for drinkingwater quality. WHO Chron. https://doi.org/10.1016/S1462 $-0758(00) 00006-6$

70. World Health Organization (2008) Guidelines for drinking-water quality. Malta

71. Sanjrani MA, MekT, Sanjrani ND et al (2018) Current situation of aqueous arsenic contamination in Pakistan, focused on Sindh and Punjab Province, Pakistan: a review. J Pollut Eff Control. https://doi.org/10.4172/2375-4397.1000207

72. Pakistan Standard Quality Control Authority (PSQCA) (2017) Pakistan Standard Quality Control Authority. Islamabad

73. Mushtaq N, Younas A, Mashiatullah A et al (2018) Hydrogeochemical and isotopic evaluation of groundwater with elevated arsenic in alkaline aquifers in Eastern Punjab, Pakistan. Chemosphere 200:576-586

74. McArthur JM, Banerjee DM, Hudson-Edwards KA et al (2004) Natural organic matter in sedimentary basins and its relation to arsenic in anoxic ground water: the example of West Bengal and its worldwide implications. Appl Geochem. https://doi. org/10.1016/j.apgeochem.2004.02.001

75. Donselaar ME, Bhatt AG, Ghosh AK (2017) On the relation between fluvio-deltaic flood basin geomorphology and the wide-spread occurrence of arsenic pollution in shallow aquifers. Sci Total Environ. https://doi.org/10.1016/j.scito tenv.2016.09.074

76. Shamsudduha M, Taylor RG, Chandler RE (2015) A generalized regression model of arsenic variations in the shallow groundwater of Bangladesh. Water Resour Res. https://doi. org/10.1002/2013WR014572

77. Majumdar D, Gupta N (2000) Nitrate pollution of groundwater and associated human health disorders. Indian J Environ Health 42:28-39

78. Spalding RF, Exner ME (2010) Occurrence of nitrate in groundwater-a review. J Environ Qual 22:392. https://doi.org/10.2134/ jeq1993.00472425002200030002x

79. Jurriëns $M$, Mollinga PP, Wester $P$ (1996) Scarcity by design: protective irrigation in India and Pakistan. ILRI, Nairobi

80. Dochartaigh BE, Macdonald AM, Darling WG et al (2010) Determining groundwater degradation from irrigation in desertmarginal northern China. Hydrogeol J. https://doi.org/10.1007/ s10040-010-0644-7

81. World Health Organization (1998) Guidelines for drinking-water quality. Guidelines for Drinking-Water Quality, 2nd edition, volume 1

82. Rhoades J, Kandiah A, Mashali A (1992) The use of saline waters for crop production

83. World Health Organization (WHO) (2011) Guidelines for drinking-water quality. WHO Chron. https://doi.org/10.1016/S1462 $-0758(00) 00006-6$

84. Tatawat RK (2014) Quality of ground water of Jaipur City, Rajasthan (India) and its suitability for domestic and irrigation purpose. Appl Ecol Environ Res. 6:79-88. https://doi. org/10.15666/aeer/0602_079088

85. Hanumant Singh Chouhan (2016) Physico-chemical investigation of ground water of Sirohi District (Raj.). J Environ Sci Comput Sci Eng Technol 5:64-74

86. Basharat $M$, Tariq A-R (2015) Groundwater modelling for need assessment of command scale conjunctive water use for addressing the exacerbating irrigation cost inequities in LBDC irrigation system, Punjab, Pakistan. Sustain Water Resour Manag 1:41-55. https://doi.org/10.1007/s40899-015-0002-y

87. Ahmad N, Sufi AB (1993) Water resources of Pakistan. Publ Shahzad Nazir, Gulberg, Lahore, Pakistan 
88. Latif M, Ahmad MZ (2009) Groundwater and soil salinity variations in a canal command area in Pakistan. Irrig Drain J Int Comm Irrig Drain 58:456-468

89. Fisher RS, Mullican WF (1997) Hydrochemical evolution of sodium-sulfate and sodium-chloride groundwater beneath the northern Chihuahuan Desert, Trans-Pecos, Texas, USA. Hydrogeol J. https://doi.org/10.1007/s100400050102

90. Li W, Wang M-Y, Liu L-Y, Yan Y (2015) Assessment of long-term evolution of groundwater hydrochemical characteristics using multiple approaches: a case study in Cangzhou, northern China. Water 7:1109-1128. https://doi.org/10.3390/w7031109

91. Farah N, Zia MA, Rehman K, Sheikh MA (2002) Quality characteristics and treatment of drinking water of Faisalabad City. Int J Agric Biol 4:347-349

92. National engineering services Pakistan (NESPAK) (2005) Punjab irrigated agriculture development sector project

93. Shamsudduha M, Taylor RG, Ahmed KM, Zahid A (2011) The impact of intensive groundwater abstraction on recharge to a shallow regional aquifer system: evidence from Bangladesh impact. Hydrogeol J. https://doi.org/10.1007/s1004 0-011-0723-4

94. Valdiya KS (2002) Emergence and evolution of Himalaya: Reconstructing history in the light of recent studies. Prog Phys Geogr. https://doi.org/10.1191/0309133302pp342ra

95. Lapworth DJ, MacDonald AM, Krishan G et al (2015) Groundwater recharge and age-depth profiles of intensively exploited groundwater resources in northwest India. Geophys Res Lett 42:7554-7562

96. Khan IA, Arsalan MH, Ghazal L et al (2018) Satellite based assessment of soil moisture and associated factors for vegetation cover: a case study of Pakistan and adjoining regions. Pakistan J Bot 50:699-709

Publisher's Note Springer Nature remains neutral with regard to jurisdictional claims in published maps and institutional affiliations. 